\title{
LEVEL II SCOUR ANALYSIS FOR BRIDGE 13 (MNTPTHOOCU0013) on CUMMINGS STREET, crossing the NORTH BRANCH WINOOSKI RIVER, MONTPELIER, VERMONT
}

Open-File Report 98-550

Prepared in cooperation with

VERMONT AGENCY OF TRANSPORTATION

and

FEDERAL HIGHWAY ADMINISTRATION

U.S. Department of the Interior U.S. Geological Survey

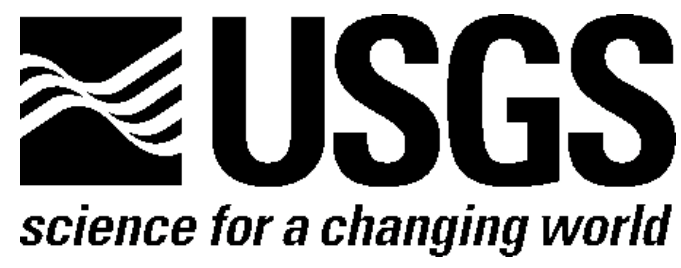




\section{LEVEL II SCOUR ANALYSIS FOR BRIDGE 13 (MNTPTHOOCU0013) on CUMMINGS STREET, crossing the NORTH BRANCH WINOOSKI RIVER, MONTPELIER, VERMONT \\ By RONDA L. BURNS and ROBERT FLYNN}

U.S. Geological Survey Open-File Report 98-550

Prepared in cooperation with

VERMONT AGENCY OF TRANSPORTATION and

FEDERAL HIGHWAY ADMINISTRATION 


\title{
U.S. DEPARTMENT OF THE INTERIOR BRUCE BABBITT, Secretary
}

\author{
U.S. GEOLOGICAL SURVEY
}

Thomas J. Casadevall, Acting Director

For additional information write to:

District Chief

U.S. Geological Survey 361 Commerce Way

Pembroke, NH 03275-3718
Copies of this report may be purchased from:

U.S. Geological Survey

Branch of Information Services

Open-File Reports Unit

Box 25286

Denver, CO 80225-0286 


\section{CONTENTS}

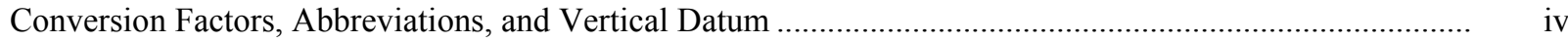

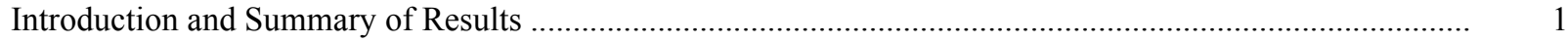

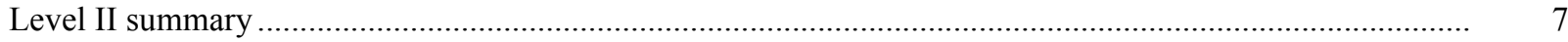

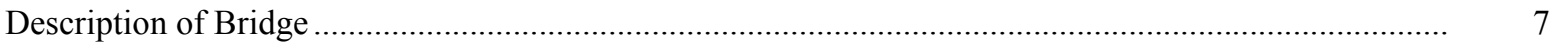

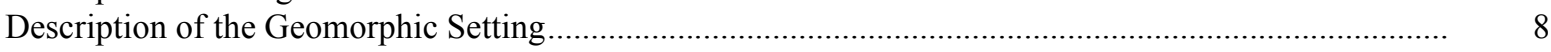

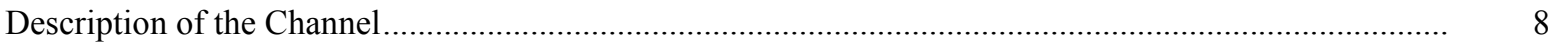

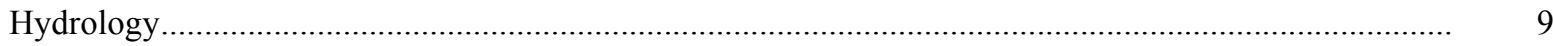

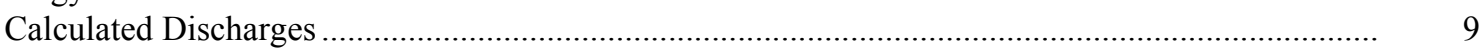

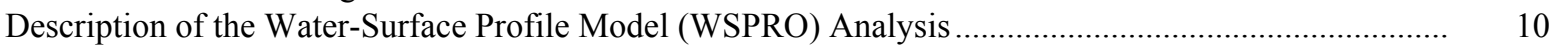

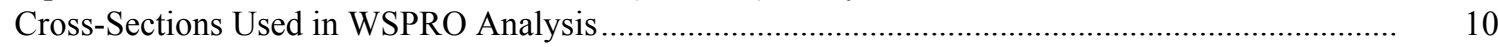

Data and Assumptions Used in WSPRO Model ........................................................................ 11

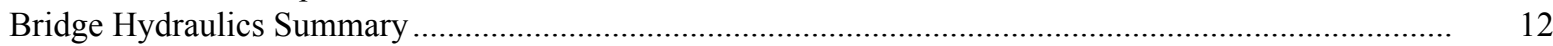

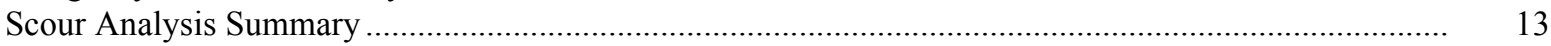

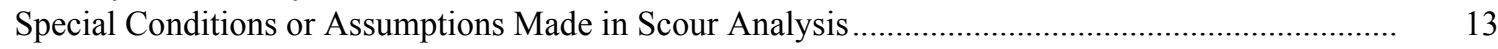

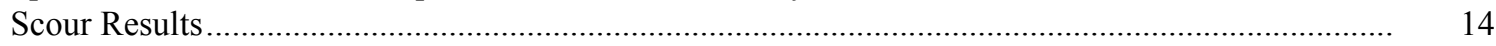

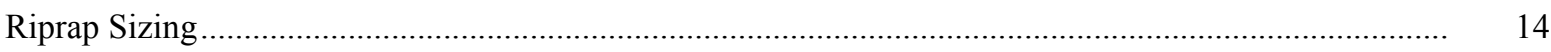

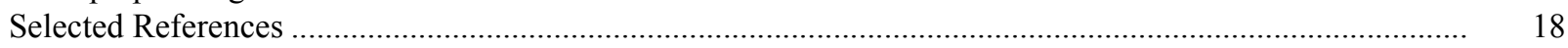

Appendices:

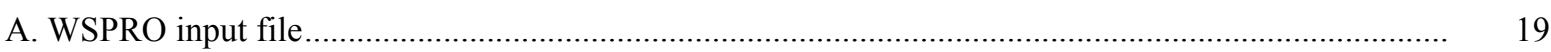

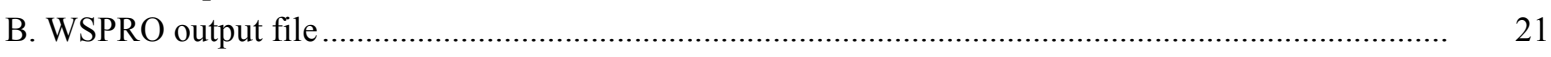

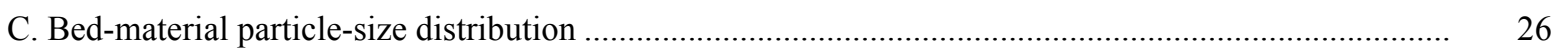

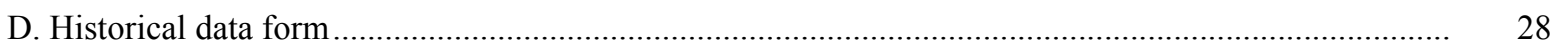

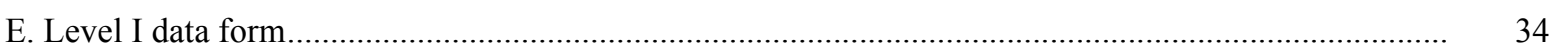

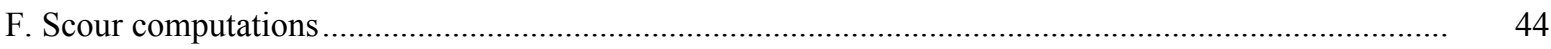

\section{FIGURES}

1. Map showing location of study area on USGS 1:24,000 scale map

2. Map showing location of study area on Vermont Agency of Transportation town highway map

3. Structure MNTPTH00CU0013 viewed from upstream (July 15, 1996).

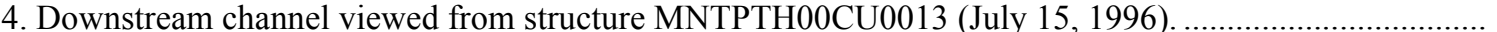

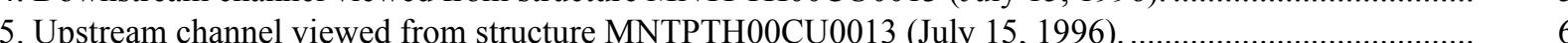

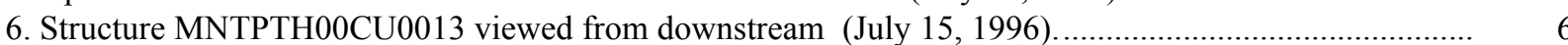

7. Water-surface profiles for the 100- and 500-year discharges at structure MNTPTH00CU0013 on Cummings Street, crossing the North Branch Winooski River, Montpelier, Vermont.

8. Scour elevations for the 100- and 500-year discharges at structure

MNTPTH00CU0013 on Cummings Street, crossing the North Branch Winooski River,

Montpelier, Vermont.

\section{TABLES}

1. Remaining footing/pile depth at abutments for the 100-year discharge at structure

MNTPTH00CU0013 on Cummings Street, crossing the North Branch Winooski River, Montpelier, Vermont.

2. Remaining footing/pile depth at abutments for the 500-year discharge at structure

MNTPTH00CU0013 on Cummings Street, crossing the North Branch Winooski River,

Montpelier, Vermont 


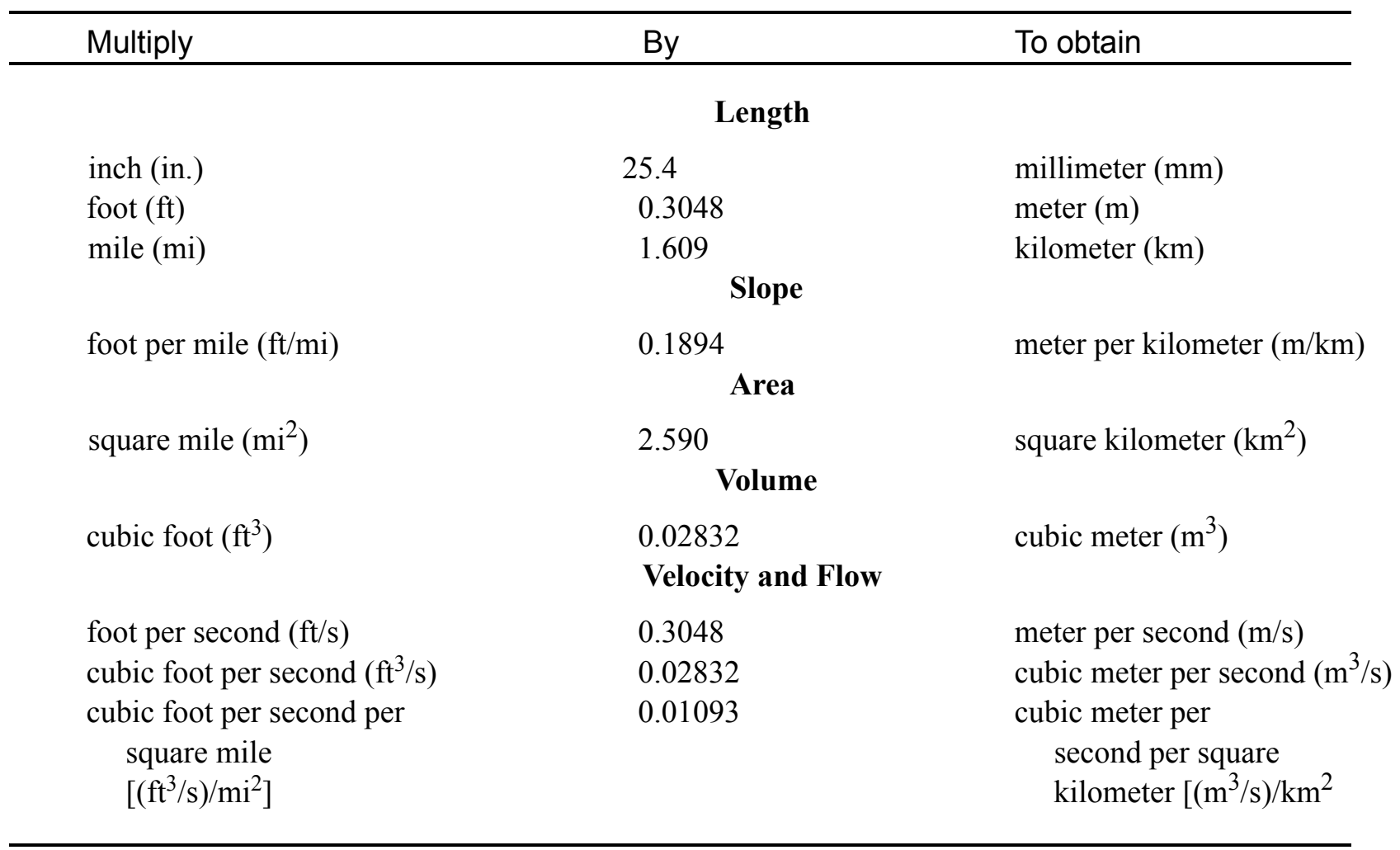

\section{OTHER ABBREVIATIONS}

$\begin{array}{lrlr}\mathrm{BF} & \text { bank full } & \text { LWW } & \text { left wingwall } \\ \mathrm{cfs} & \text { cubic feet per second } & \text { Max } & \text { maximum } \\ \mathrm{D}_{50} & \text { median diameter of bed material } & \text { MC } & \text { main channel } \\ \mathrm{DS} & \text { downstream } & \text { RAB } & \text { right abutment } \\ \mathrm{elev} & \text { elevation } & \text { RABUT } & \text { face of right abutment } \\ \mathrm{f} / \mathrm{p} & \text { flood plain } & \text { RB } & \text { right bank } \\ \mathrm{ft} & \text { square feet } & \text { ROB } & \text { right overbank } \\ \mathrm{ft} / \mathrm{ft} & \text { feet per foot } & \text { RWW } & \text { right wingwall } \\ \mathrm{FEMA} & \text { Federal Emergency Management Agency } & \text { TH } & \text { town highway } \\ \mathrm{FHWA} & \text { Federal Highway Administration } & \text { UB } & \text { under bridge } \\ \mathrm{JCT} & \text { junction } & \text { US } & \text { upstream } \\ \text { LAB } & \text { left abutment } & \text { USGS } & \text { United States Geological Survey } \\ \text { LABUT } & \text { face of left abutment } & \text { VTAOT } & \text { Vermont Agency of Transportation } \\ \text { LB } & \text { left bank } & \text { WSPRO } & \text { water-surface profile model } \\ \text { LOB } & \text { left overbank } & \text { yr } & \text { year }\end{array}$

In this report, the words "right" and "left" refer to directions that would be reported by an observer facing downstream. Sea level: In this report, "sea level" refers to the National Geodetic Vertical Datum of 1929-- a geodetic datum derived from a general adjustment of the first-order level nets of the United States and Canada, formerly called Sea Level Datum of 1929.

In the appendices, the above abbreviations may be combined. For example, USLB would represent upstream left bank. 


\title{
LEVEL II SCOUR ANALYSIS FOR BRIDGE 13 (MNTPTHOOCU0013) ON CUMMINGS STREET, CROSSING THE NORTH BRANCH WINOOSKI RIVER, MONTPELIER, VERMONT
}

\author{
By Ronda L. Burns and Robert Flynn
}

\section{INTRODUCTION AND SUMMARY OF RESULTS}

This report provides the results of a detailed Level II analysis of scour potential at structure MNTPTH00CU0013 on Cummings Street crossing the North Branch Winooski River, Montpelier, Vermont (figures 1-8). A Level II study is a basic engineering analysis of the site, including a quantitative analysis of stream stability and scour (FHWA, 1993). Results of a Level I scour investigation also are included in appendix E of this report. A Level I investigation provides a qualitative geomorphic characterization of the study site. Information on the bridge, gleaned from Vermont Agency of Transportation (VTAOT) files, was compiled prior to conducting Level I and Level II analyses and is found in appendix D.

The site is in the New England Upland section of the New England physiographic province in north-central Vermont. The $76.5-\mathrm{mi}^{2}$ drainage area is in a predominantly rural and forested basin. In the vicinity of the study site, the surface cover is pasture upstream of the bridge and shrub and brushland downstream of the bridge.

In the study area, the North Branch Winooski River has an incised, sinuous channel with a slope of approximately $0.0002 \mathrm{ft} / \mathrm{ft}$, an average channel top width of $114 \mathrm{ft}$ and an average bank height of $5 \mathrm{ft}$. The channel bed material ranges from organics to silt and clay with a median grain size $\left(\mathrm{D}_{50}\right)$ of $1.28 \mathrm{~mm}(0.0042 \mathrm{ft})$. The geomorphic assessment at the time of the Level I and Level II site visit on July 15, 1996, indicated that the reach was stable.

The Cummings Street crossing of the North Branch Winooski River is a 64-ft-long, twolane bridge consisting of one 61-foot steel-beam span (Vermont Agency of Transportation, written communication, October 13, 1995). The opening length of the structure parallel to the bridge face is $59.0 \mathrm{ft}$. The bridge is supported by vertical, concrete abutments with wingwalls on the upstream right and the downstream left corners of the structure. The channel is not skewed to the opening and the opening-skew-to-roadway is zero degrees. 
A scour hole $8 \mathrm{ft}$ deeper than the mean thalweg depth was observed along the right side of the channel under the bridge during the Level I assessment. The scour protection measure at the site was type-2 stone fill (less than 36 inches diameter) along the upstream left bank, the downstream left wingwall, and the right abutment. Additional details describing conditions at the site are included in the Level II Summary and appendices D and E.

Scour depths and recommended rock rip-rap sizes were computed using the general guidelines described in Hydraulic Engineering Circular 18 (Richardson and Davis, 1995) for the 100- and 500-year discharges. Total scour at a highway crossing is comprised of three components: 1) long-term streambed degradation; 2) contraction scour (due to accelerated flow caused by a reduction in flow area at a bridge) and; 3 ) local scour (caused by accelerated flow around piers and abutments). Total scour is the sum of the three components. Equations are available to compute depths for contraction and local scour and a summary of the results of these computations follows.

Contraction scour for all modelled flows ranged from 0.9 to $1.7 \mathrm{ft}$. The worst-case contraction scour occurred at the 500-year discharge. Abutment scour ranged from 8.1 to $18.3 \mathrm{ft}$. The worst-case abutment scour occurred at the 500-year discharge. Additional information on scour depths and depths to armoring are included in the section titled "Scour Results." Scoured-streambed elevations, based on the calculated scour depths, are presented in tables 1 and 2. A cross-section of the scour computed at the bridge is presented in figure 8. Scour depths were calculated assuming an infinite depth of erosive material and a homogeneous particle-size distribution.

It is generally accepted that the Froehlich equation (abutment scour) gives "excessively conservative estimates of scour depths" (Richardson and Davis, 1995, p. 46). Usually, computed scour depths are evaluated in combination with other information including (but not limited to) historical performance during flood events, the geomorphic stability assessment, existing scour protection measures, and the results of the hydraulic analyses. Therefore, scour depths adopted by VTAOT may differ from the computed values documented herein. 


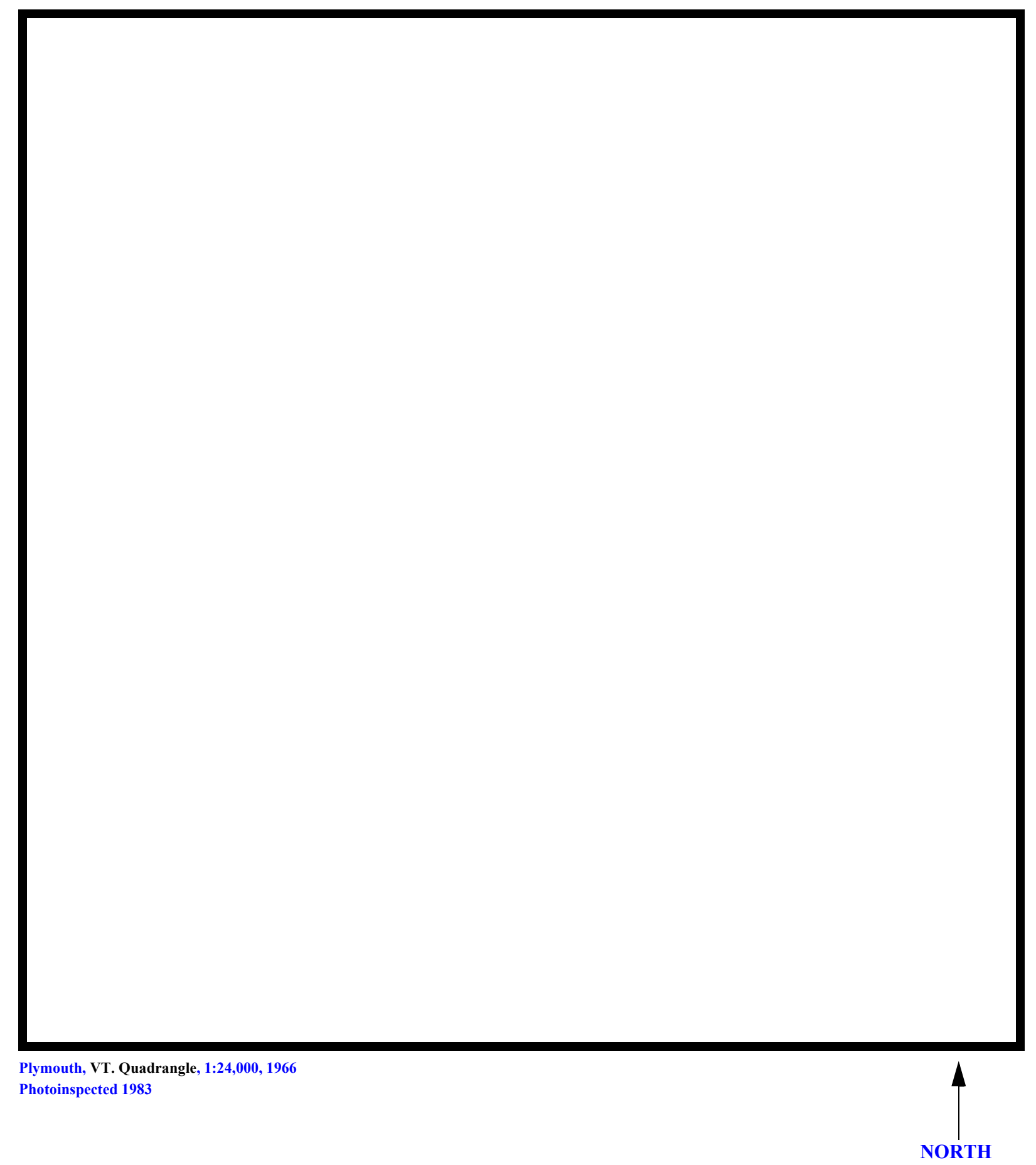

Figure 1. Location of study area on USGS 1:24,000 scale map. 
Figure 2. Location of study area on Vermont Agency of Transportation town highway map. 

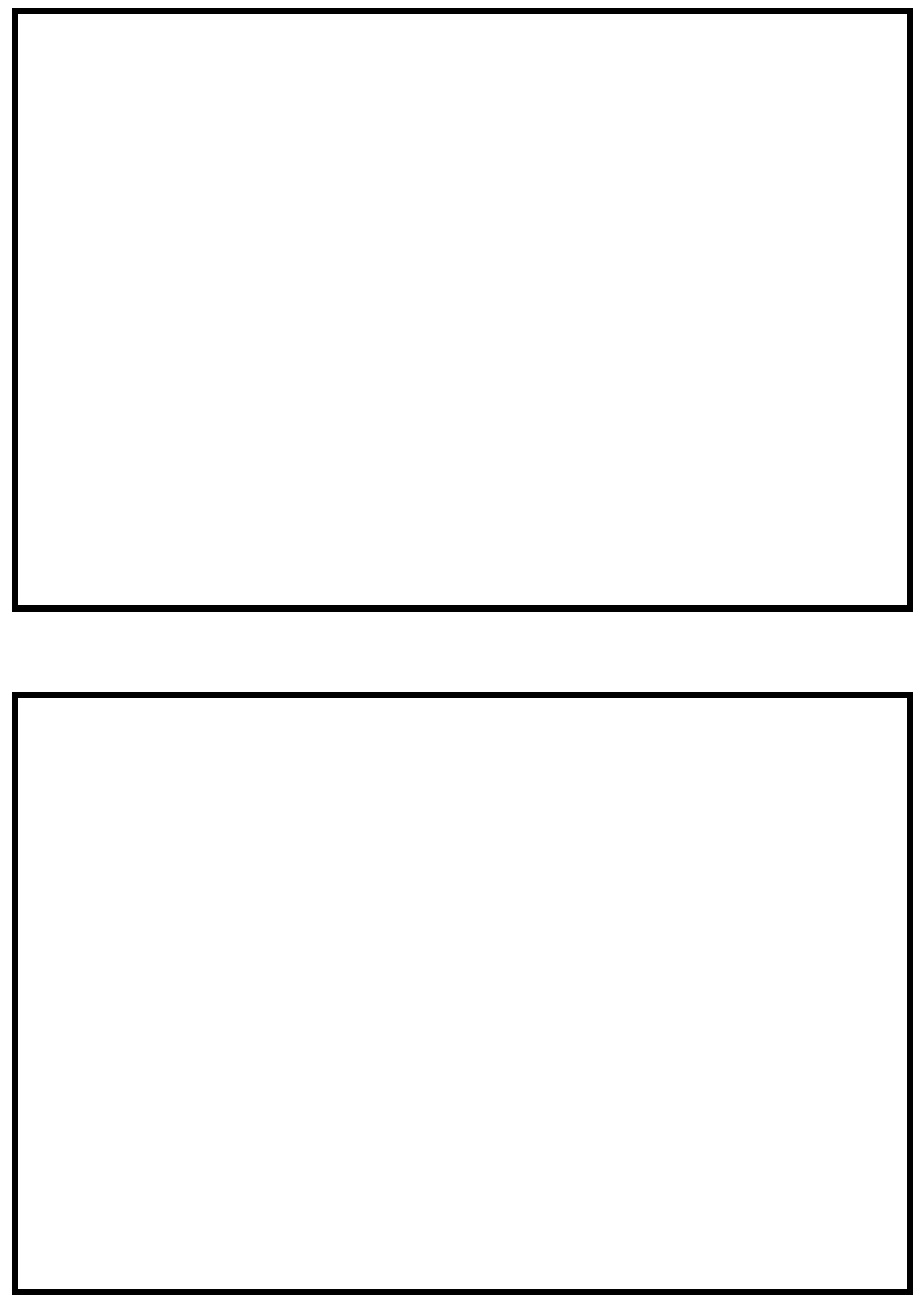

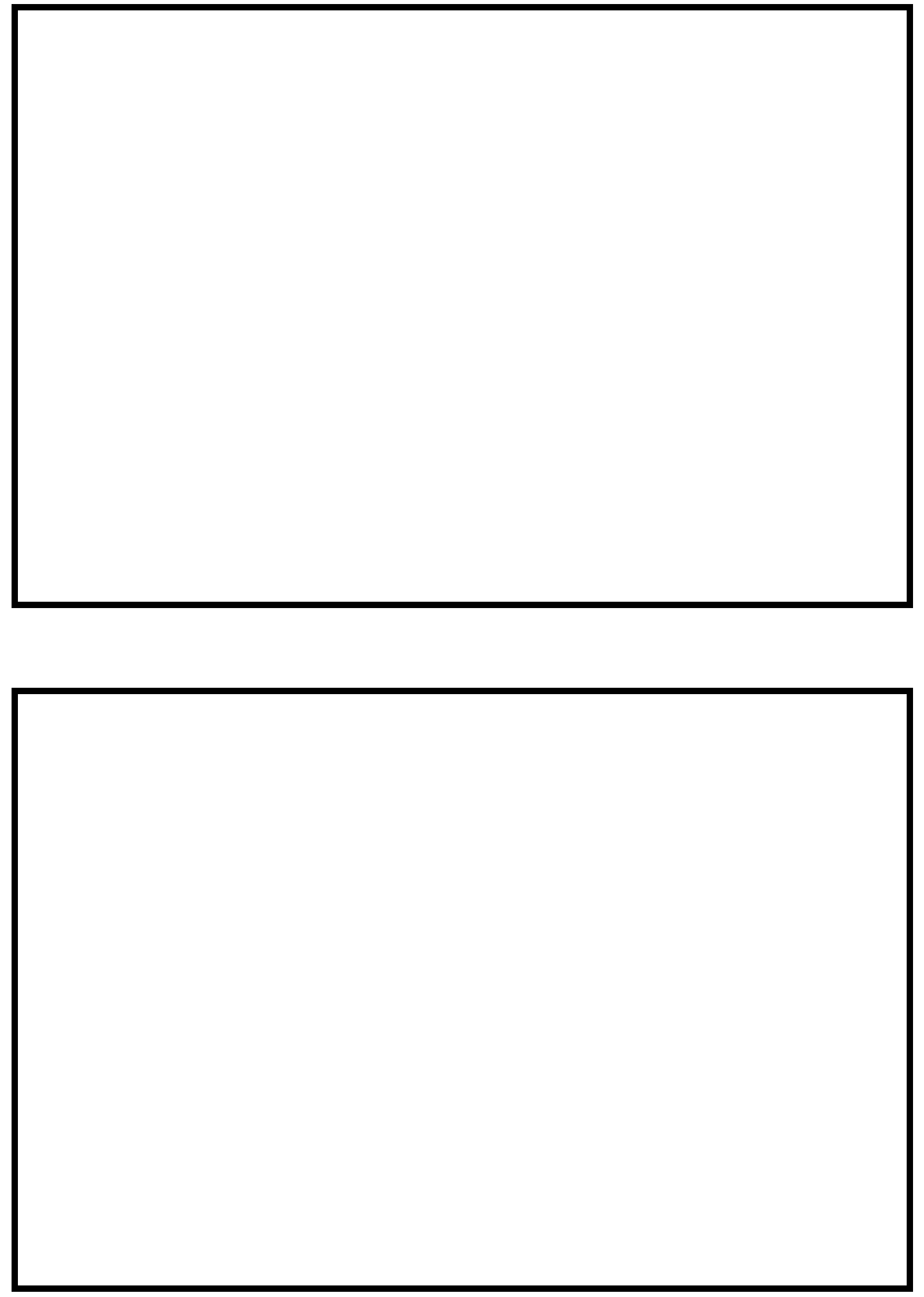


\section{LEVEL II SUMMARY}

\begin{tabular}{llllll} 
& Structure Number & MNTPTH00CU0013 & & \multicolumn{3}{c}{ North Branch Winooski River } \\
County & Washington & Road $\underline{\text { Cummings St. }}$ District & 6
\end{tabular}

\section{Description of Bridge}

Bridge length $\frac{64}{f t}$ Bridge width $\frac{19.1}{f t}$ Max span length $\frac{61}{f t}$ Alignment of bridge to road (on curve or straight)

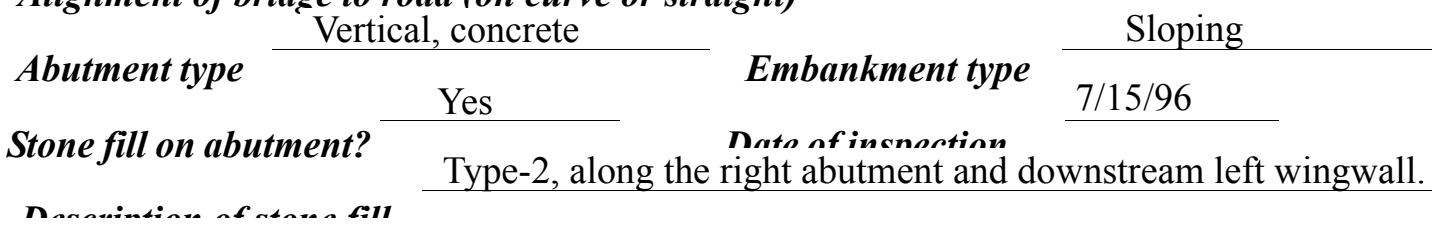

Abutments and wingwalls are concrete.

No

\section{$0 \quad$ Yes}

Is bridge skewed to flood flow according to The ' survey? Angle

channel makes a slight bend through the bridge.

Debris accumulation on bridge at time of Level I or Level II site visit:

\begin{tabular}{|c|c|c|c|}
\hline & $\begin{array}{c}\text { Date of insmortion } \\
\underline{7 / 15 / 96}\end{array}$ & $\begin{array}{l}\text { Percent of abmunal } \\
\text { blocked inortzontatly }\end{array}$ & $\begin{array}{l}\text { Percent of } 0 \\
\text { blocked verticatty }\end{array}$ \\
\hline & $7 / 15 / 96$ & 0 & 0 \\
\hline & Low. & & \\
\hline
\end{tabular}

\section{Potential for debris}

None as of 7/15/96.

Dosrriho any, foaturos noar ar at tho hridoo that mav, affort flow, (includo ahsorvation dato) 


\section{Description of the Geomorphic Setting}

General topography The channel is located in a low relief valley with a narrow flood plain.

$7 / 15 / 96$

Geomorphic conditions at bridge site: downstream (DS), upstream (US)

Date of inspection Moderately

DS left: $\quad$ sloped channel bank and overbank

DS right: Steep channel bank to a narrow flood plain

US left: $\quad$ Steep channel bank to a narrow flood plain

US right: $\quad$ Steep channel bank to a narrow flood plain

\section{Description of the Channel}

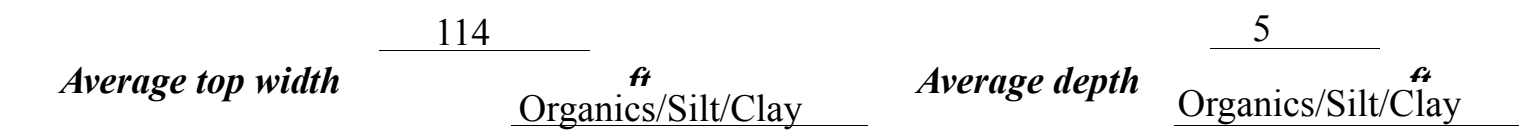

Predominant bed material

Bank material

Sinuous but stable

with semi-allúvial channel boundaries and narrow point bars.

Vegetative co 1 Shrubs and brush

DS left: $\quad$ Shrubs and brush

DS right: $\quad$ Grass

US left: $\quad$ Grass

US right: $\quad$ Yes

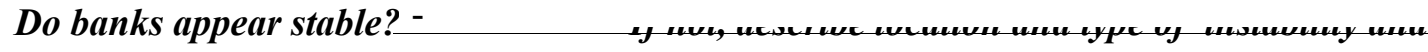

date of observatton.

There is a dam

approximately 2,500 ft downstream, as observed on 7/15/96.

Describe any obstructions in channel and date of observation. 


\section{Hydrology}

Drainage area $\stackrel{76.5}{\mathrm{mi}^{2}}$

Percentage of drainage area in physiographic provinces: (approximate)

Physiographic province/section New England/New England Upland
Percent of drainage area 100

Is drainage area considered rural or urban? Rural Describe any significant urbanization:

There are houses on the upstream and downstream right overbanks and on the upstream left overbank.

Yes

Is there a USGS gage on the stream of interest?

USGS gage description

North Branch Winooski River at Wrightsville, VT

04285500

USGS gage number

Gage drainage area $\frac{69.2}{\boldsymbol{m i}^{2}}$

No

Is there a lake' -

- $\cdots \cdot(n+1)$

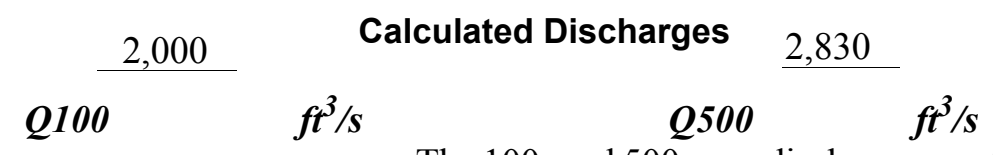

The 100- and 500-year discharges are flood frequency

Mestimates for the North Branch Winooski River at the confluence with the Winooski River documented in the Flood Insurance Study for the City of Montpelier (FEMA, 1981). These discharges were within a range defined by flood frequency curves developed from several empirical methods (Benson, 1962; Johnson and Tasker, 1974; FHWA, 1983; Potter, 1957a\&b;

Talbot, 1887). Each curve was extended graphically to the 500 -year event. 


\section{Description of the Water-Surface Profile Model (WSPRO) Analysis}

Datum for WSPRO analysis (USGS survey, sea level, VTAOT plans) ～USGS survey

Datum tie between USGS survey and VTAOT plans $\quad$ Subtract $406.3 \mathrm{ft}$ from the USGS

arbitrary survey datum to obtain the VTAOT plans' datum. Add $35.5 \mathrm{ft}$ to the USGS arbitrary survey datum to obtain the National Geodetic Vertical Datum of $1929 .$.

Description of reference marks used to determine USGS datum. $\quad$ RM1 is the top of a hydrant on the west side of Elm Street at the corner of Cummings Street and Elm Street (elev.

$507.34 \mathrm{ft}$, arbitrary survey datum). RM2 is a nail, $1.25 \mathrm{ft}$ above the ground, in an utility pole on the upstream left overbank (elev. $500.29 \mathrm{ft}$, arbitrary survey datum).

\section{Cross-Sections Used in WSPRO Analysis}

${ }^{1}$ For location of cross-sections see plan-view sketch included with Level I field form, appendix E. For more detail on how cross-sections were developed see WSPRO input file. 


\section{Data and Assumptions Used in WSPRO Model}

Hydraulic analyses of the reach were done by use of the Federal Highway Administration's WSPRO step-backwater computer program (Shearman and others, 1986, and Shearman, 1990). The analyses reported herein reflect conditions existing at the site at the time of the study. Furthermore, in the development of the model it was necessary to assume no accumulation of debris or ice at the site. Results of the hydraulic model are presented in the Bridge Hydraulic Summary, appendix B, and figure 7.

Channel roughness factors (Manning's " $n$ ") used in the hydraulic model were estimated using field inspections at each cross section following the general guidelines described by Arcement and Schneider (1989). Final adjustments to the values were made during the modelling of the reach. Channel " $\mathrm{n}$ " values for the reach ranged from 0.030 to 0.048 , and overbank " $n$ " values ranged from 0.040 to 0.060 .

At the exit section (EXITX), the starting water surface was obtained from the flood profiles presented in the Flood Insurance Study for the City of Montpelier (Federal Emergency Management Agency, 1981). Section G in the Flood Insurance Study was assumed to be at the same location as the exit section surveyed for this analysis.

The surveyed approach section (APTEM) was moved along the approach channel slope $(0.0083 \mathrm{ft} / \mathrm{ft})$ to establish the modelled approach section (APPR1), one bridge length upstream of the upstream face as recommended by Shearman and others (1986). This location provides a consistent method for determining scour variables. 


\section{Bridge Hydraulics Summary}

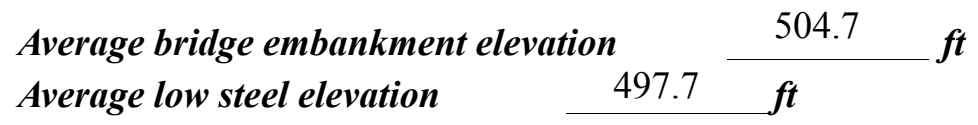

100-year discharge $\quad 2,000 \quad \mathrm{ft}^{3} / \mathrm{s}$

Water-surface elevation in bridge opening $493.1 \quad f t$

Road overtopping? ___ No Discharge over road ___ -- $\mathrm{ft}^{3} / \mathrm{s}$

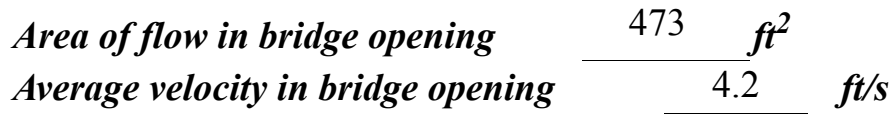

Maximum WSPRO tube velocity at bridge $\quad 5.5 \mathrm{ft} / \mathrm{s}$

Water-surface elevation at Approach section with bridge 493.4

Water-surface elevation at Approach section without bridge $\quad \overline{493.3}$

Amount of backwater caused by bridge $\quad 0.1 \quad$ it

500-year discharge $\quad 2,830 \quad \mathrm{ft}^{3} / \mathrm{s}$

Water-surface elevation in bridge opening

$494.1 \mathrm{ft}$

Road overtopping? ___ No Discharge over road ___ -- $\quad, t^{3} / s$

Area of flow in bridge opening $\quad 528 \quad \mathrm{ft}^{2}$

Average velocity in bridge opening $5.4 \mathrm{ft} / \mathrm{s}$

Maximum WSPRO tube velocity at bridge 6.9 _

Water-surface elevation at Approach section with bridge 494.6

Water-surface elevation at Approach section without bridge $\quad 494.3$

Amount of backwater caused by bridge 0.3 .t

Incipient overtopping discharge ___ -- $\mathrm{ft}^{3} / \mathrm{s}$

Water-surface elevation in bridge opening $\quad--\quad t$

Area of flow in bridge opening _ $\quad--\quad \mathrm{ft}^{2}$

Average velocity in bridge opening $\quad--\quad f t / s$

Maximum WSPRO tube velocity at bridge _-- $\mathrm{ft} / \mathrm{s}$

Water-surface elevation at Approach section with bridge

Water-surface elevation at Approach section without bridge

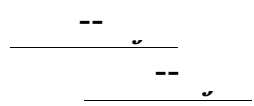

Amount of backwater caused by bridge _ 


\section{Scour Analysis Summary}

\section{Special Conditions or Assumptions Made in Scour Analysis}

Scour depths were computed using the general guidelines described in Hydraulic Engineering Circular 18 (Richardson and Davis, 1995). Scour depths were calculated assuming an infinite depth of erosive material and a homogeneous particle-size distribution. The results of the scour analyses for the 100- and 500-year discharges are presented in tables 1 and 2 and the scour depths are shown graphically in figure 8 .

Contraction scour for the 100-year and 500-year discharges was computed by use of the Laursen live-bed contraction scour equation (Richardson and Davis, 1995, p. 30, equation 17). Abutment scour was computed by use of the Froehlich equation (Richardson and Davis, 1995, p. 48, equation 28). Variables for the Froehlich equation include the Froude number of the flow approaching the embankments, the length of the embankment blocking flow, and the depth of flow approaching the embankment less any roadway overtopping. 


\section{Scour Results}

Contraction scour:

$\begin{array}{rrr}\text { 100-year } & \text { Incipient } \\ \text { discharge } & \text { discharge } & \text { overtopping } \\ \text { discharge }\end{array}$

(Scour depths in feet)

Main channel

Live-bed scour

0.9

Clear-water scour

Depth to armoring

Left overbank

Right overbank
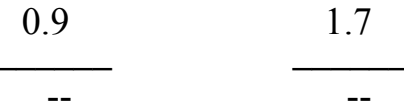

$\mathrm{N} / \mathrm{A}^{-}$

$\mathrm{N} / \mathrm{A}^{-}$

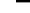

$--$

$--^{-}$
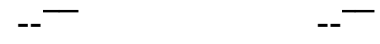

$--$

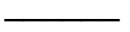

Local scour:

Abutment scour

Left abutment

8.1

9.9

15.5

18.3-

Right abutment

Pier scour

Pier 1

Pier 2

Pier 3

\section{Riprap Sizing}

Abutments:

Left abutment
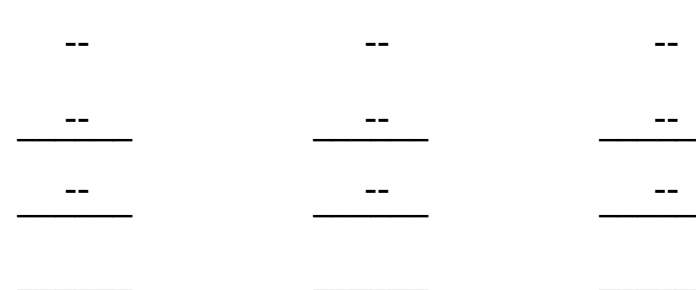

Right abutment

Piers:

Pier 1

Pier 2

\section{0-year \\ discharge}

0.5

0.5
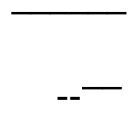

$--$

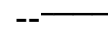

Incipient

500-year overtopping discharge discharge ( $D_{50}$ in feet) 0.7

\section{7}
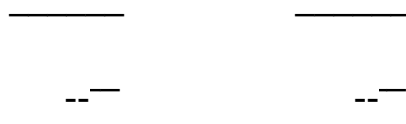

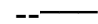




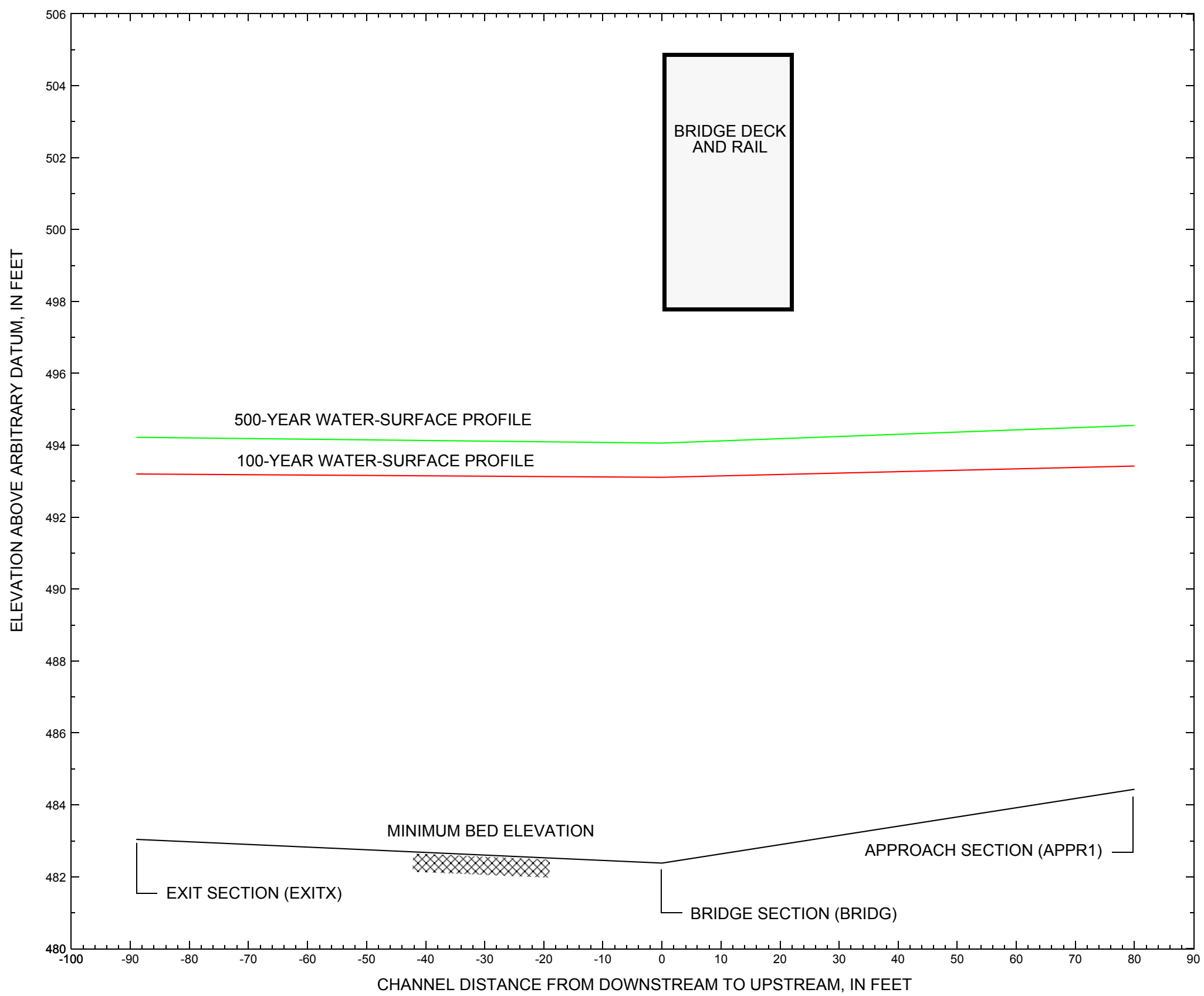

Figure 7. Water-surface profiles for the 100- and 500-year discharges at structure MNTPTH00CU0013 on Cummings Street, crossing the North Branch Winooski River, Montpelier, Vermont. 


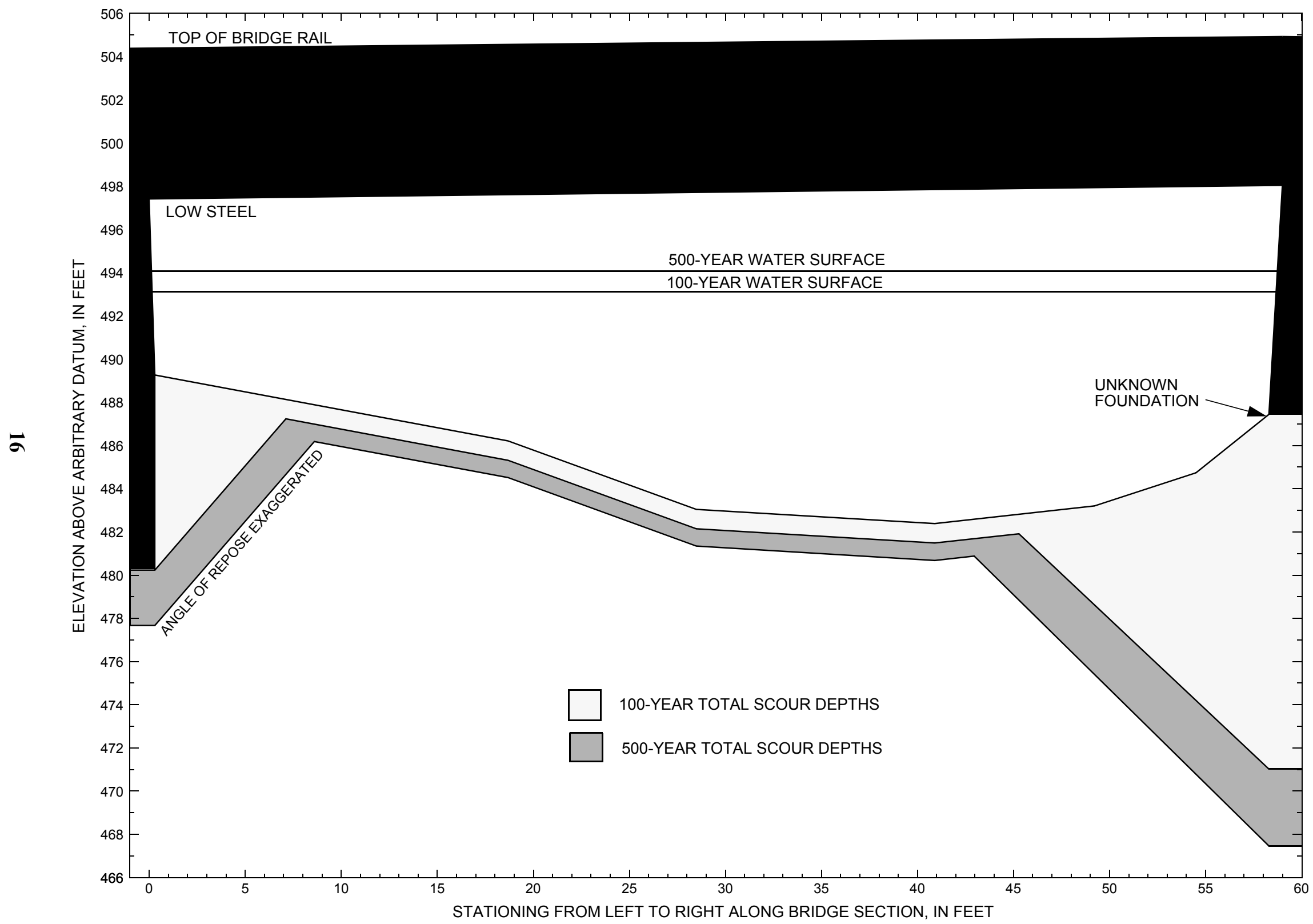

Figure 8. Scour elevations for the 100- and 500-year discharges at structure MNTPTH00CU0013 on Cummings Street, crossing the North Branch Winooski River, Montpelier, Vermont. 


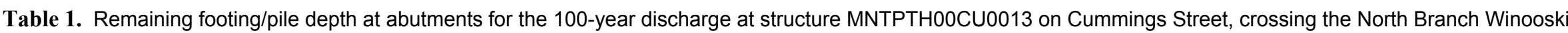
River, Montpelier, Vermont.

[VTAOT, Vermont Agency of Transportation; --, no data]

\begin{tabular}{|c|c|c|c|c|c|c|c|c|c|c|c|}
\hline Description & Station $^{1}$ & $\begin{array}{l}\text { VTAOT } \\
\text { minimum } \\
\text { bridge seat } \\
\text { elevation } \\
\text { (feet) }\end{array}$ & $\begin{array}{c}\text { Surveyed } \\
\text { minimum } \\
\text { low-chord } \\
\text { elevation } \\
\text { (feet) }\end{array}$ & $\begin{array}{c}\text { Bottom of } \\
\text { footing/pile } \\
\text { elevation }{ }^{2} \\
\text { (feet) }\end{array}$ & $\begin{array}{c}\text { Channel } \\
\text { elevation at } \\
\text { abutment/ } \\
\text { pier }^{2} \\
\text { (feet) }\end{array}$ & $\begin{array}{l}\text { Contraction } \\
\text { scour depth } \\
\text { (feet) }\end{array}$ & $\begin{array}{l}\text { Abutment } \\
\text { scour } \\
\text { depth } \\
\text { (feet) }\end{array}$ & $\begin{array}{l}\text { Pier } \\
\text { scour } \\
\text { depth } \\
\text { (feet) }\end{array}$ & $\begin{array}{l}\text { Depth of } \\
\text { total scour } \\
\text { (feet) }\end{array}$ & $\begin{array}{c}\text { Elevation of } \\
\text { scour }^{2} \\
\text { (feet) }\end{array}$ & $\begin{array}{c}\text { Remaining } \\
\text { footing/pile } \\
\text { depth } \\
\text { (feet) }\end{array}$ \\
\hline \multicolumn{12}{|c|}{100 -year discharge is 2,000 cubic-feet per second } \\
\hline Left abutment & 0.0 & 91.3 & 497.4 & 480.3 & 489.3 & 0.9 & 8.1 & -- & 9.0 & 480.3 & 0.0 \\
\hline Right abutment & 59.0 & 91.8 & 498.0 & -- & 487.4 & 0.9 & 15.5 & -- & 16.4 & 471.0 & -- \\
\hline
\end{tabular}

1.Measured along the face of the most constricting side of the bridge.

2.Arbitrary datum for this study.

Table 2. Remaining footing/pile depth at abutments for the 500-year discharge at structure MNTPTH00CU0013 on Cummings Street, crossing the North Branch Winooski River, Montpelier, Vermont.

[VTAOT, Vermont Agency of Transportation; --, no data]

\begin{tabular}{|c|c|c|c|c|c|c|c|c|c|c|c|}
\hline Description & Station $^{1}$ & $\begin{array}{l}\text { VTAOT } \\
\text { minimum } \\
\text { bridge seat } \\
\text { elevation } \\
\text { (feet) }\end{array}$ & $\begin{array}{c}\text { Surveyed } \\
\text { minimum } \\
\text { low-chord } \\
\text { elevation } \\
\text { (feet) }\end{array}$ & $\begin{array}{c}\text { Bottom of } \\
\text { footing/pile } \\
\text { elevation }{ }^{2} \\
\text { (feet) }\end{array}$ & $\begin{array}{c}\text { Channel } \\
\text { elevation at } \\
\text { abutment/ } \\
\text { pier }^{2} \\
\text { (feet) }\end{array}$ & $\begin{array}{l}\text { Contraction } \\
\text { scour depth } \\
\text { (feet) }\end{array}$ & $\begin{array}{c}\text { Abutment } \\
\text { scour } \\
\text { depth } \\
\text { (feet) }\end{array}$ & $\begin{array}{l}\text { Pier } \\
\text { scour } \\
\text { depth } \\
\text { (feet) }\end{array}$ & $\begin{array}{l}\text { Depth of } \\
\text { total scour } \\
\text { (feet) }\end{array}$ & $\begin{array}{c}\text { Elevation of } \\
\text { scour }^{2} \\
\text { (feet) }\end{array}$ & $\begin{array}{c}\text { Remaining } \\
\text { footing/pile } \\
\text { depth } \\
\text { (feet) }\end{array}$ \\
\hline \multicolumn{12}{|c|}{500 -year discharge is 2,830 cubic-feet per second } \\
\hline Left abutment & 0.0 & 91.3 & 497.4 & 480.3 & 489.3 & 1.7 & 9.9 & -- & 11.6 & 477.7 & -2.6 \\
\hline Right abutment & 59.0 & 91.8 & 498.0 & -- & 487.4 & 1.7 & 18.3 & -- & 20.0 & 467.4 & -- \\
\hline
\end{tabular}

1.Measured along the face of the most constricting side of the bridge.

2.Arbitrary datum for this study. 


\section{SELECTED REFERENCES}

Arcement, G.J., Jr., and Schneider, V.R., 1989, Guide for selecting Manning's roughness coefficients for natural channels and flood plains:

U.S. Geological Survey Water-Supply Paper 2339, 38 p.

Barnes, H.H., Jr., 1967, Roughness characteristics of natural channels: U.S. Geological Survey Water-Supply Paper 1849,213 p.

Benson, M. A., 1962, Factors Influencing the Occurrence of Floods in a Humid Region of Diverse Terrain: U.S. Geological Survey WaterSupply Paper 1580-B, 64 p.

Brown, S.A. and Clyde, E.S., 1989, Design of riprap revetment: Federal Highway Administration Hydraulic Engineering Circular No. 11, Publication FHWA-IP-89-016, 156 p.

Federal Emergency Management Agency, 1981, Flood Insurance Study, City of Montpelier, Washington County, Vermont: Washington, D.C., August 17, 1981.

Federal Highway Administration, 1983, Runoff estimates for small watersheds and development of sound design: Federal Highway Administration Report FHWA-RD-77-158.

Federal Highway Administration, 1993, Stream Stability and Scour at Highway Bridges: Participant Workbook: Federal Highway Administration Report FHWA-HI-91-011.

Froehlich, D.C., 1989, Local scour at bridge abutments in Ports, M.A., ed., Hydraulic Engineering--Proceedings of the 1989 National Conference on Hydraulic Engineering: New York, American Society of Civil Engineers, p. 13-18.

Hayes, D.C.,1993, Site selection and collection of bridge-scour data in Delaware, Maryland, and Virginia: U.S. Geological Survey WaterResources Investigation Report 93-4017, 23 p.

Interagency Advisory Committee on Water Data, 1982, Guidelines for determining flood flow frequency: U.S. Geological Survey, Bulletin 17B of the Hydrology Subcommittee, 190 p.

Johnson, C.G. and Tasker, G.D.,1974, Progress report on flood magnitude and frequency of Vermont streams: U.S. Geological Survey OpenFile Report 74-130, 37 p.

Lagasse, P.F., Schall, J.D., Johnson, F., Richardson, E.V., Chang, F., 1995, Stream Stability at Highway Structures: Federal Highway Administration Hydraulic Engineering Circular No. 20, Publication FHWA-IP-90-014, 144 p.

Laursen, E.M., 1960, Scour at bridge crossings: Journal of the Hydraulics Division, American Society of Civil Engineers, v. 86, no. HY2, p. 39-53.

Potter, W. D., 1957a, Peak rates of runoff in the Adirondack, White Mountains, and Maine woods area, Bureau of Public Roads

Potter, W. D., 1957b, Peak rates of runoff in the New England Hill and Lowland area, Bureau of Public Roads

Richardson, E.V. and Davis, S.R., 1995, Evaluating scour at bridges: Federal Highway Administration Hydraulic Engineering Circular No. 18, Publication FHWA-IP-90-017, 204 p.

Richardson, E.V., Simons, D.B., and Julien, P.Y., 1990, Highways in the river environment: Federal Highway Administration Publication FHWA-HI-90-016.

Ritter, D.F., 1984, Process Geomorphology: W.C. Brown Co., Debuque, Iowa, 603 p.

Shearman, J.O., 1990, User's manual for WSPRO--a computer model for water surface profile computations: Federal Highway Administration Publication FHWA-IP-89-027, 187 p.

Shearman, J.O., Kirby, W.H., Schneider, V.R., and Flippo, H.N., 1986, Bridge waterways analysis model; research report: Federal Highway Administration Publication FHWA-RD-86-108, 112 p.

Talbot, A.N., 1887, The determination of water-way for bridges and culverts.

U.S. Geological Survey, 1968, Montpelier, Vermont 7.5 Minute Series quadrangle map: U.S. Geological Survey Topographic Maps, Scale $1: 24,000$. 


\section{APPENDIX A: \\ WSPRO INPUT FILE}




\section{WSPRO INPUT FILE}

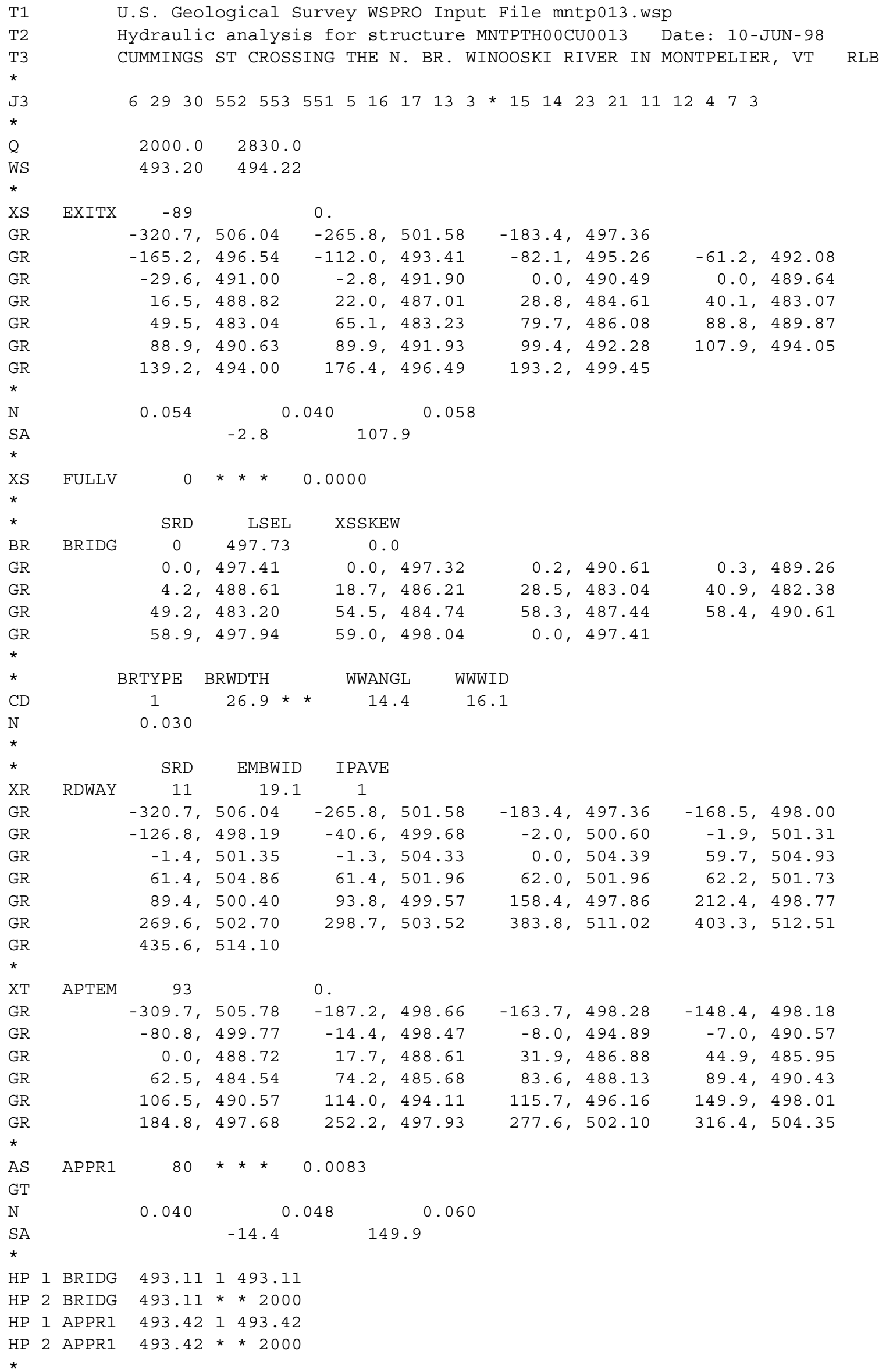




\section{APPENDIX B: \\ WSPRO OUTPUT FILE}


WSPRO OUTPUT FILE

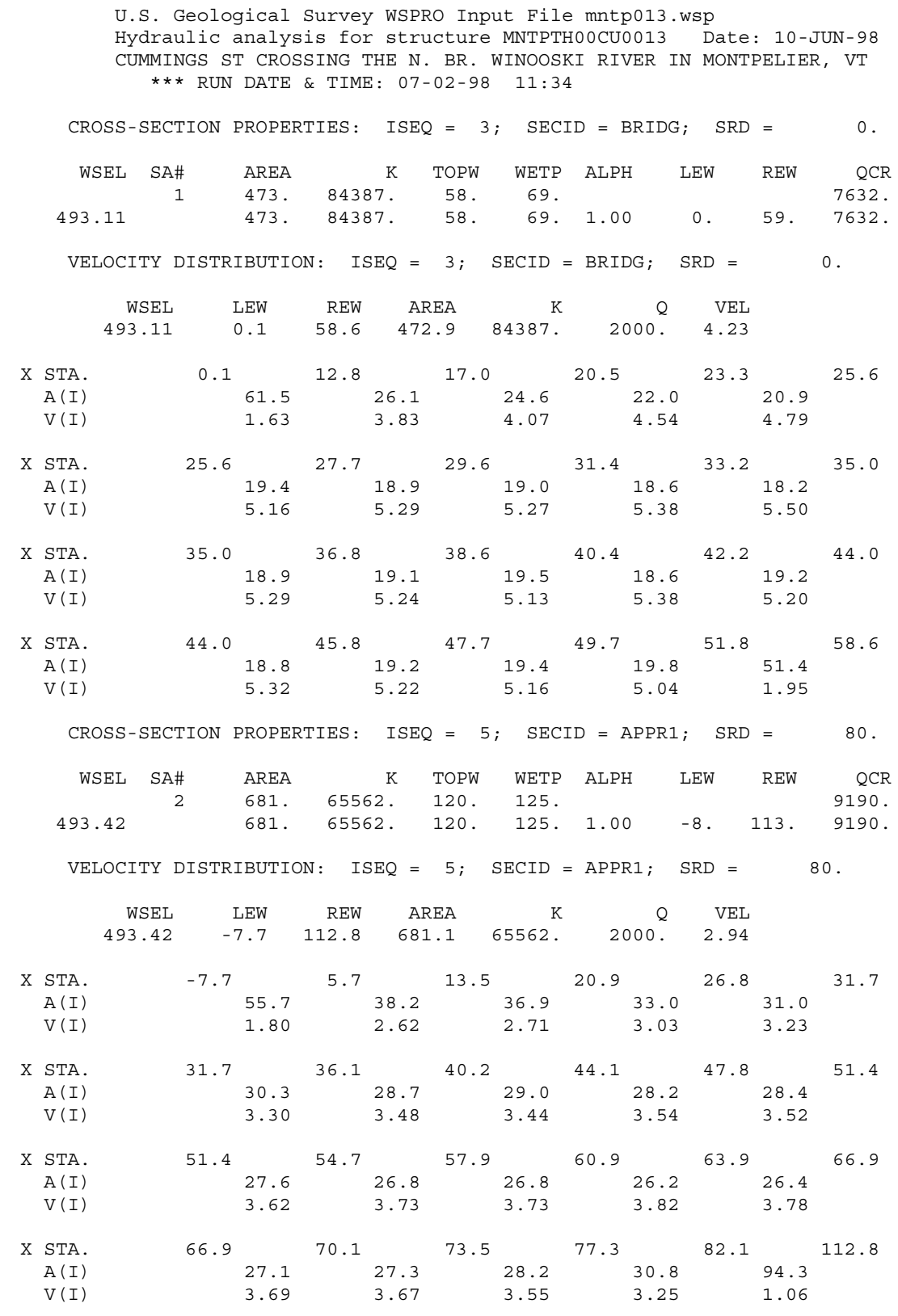


WSPRO OUTPUT FILE (continued)

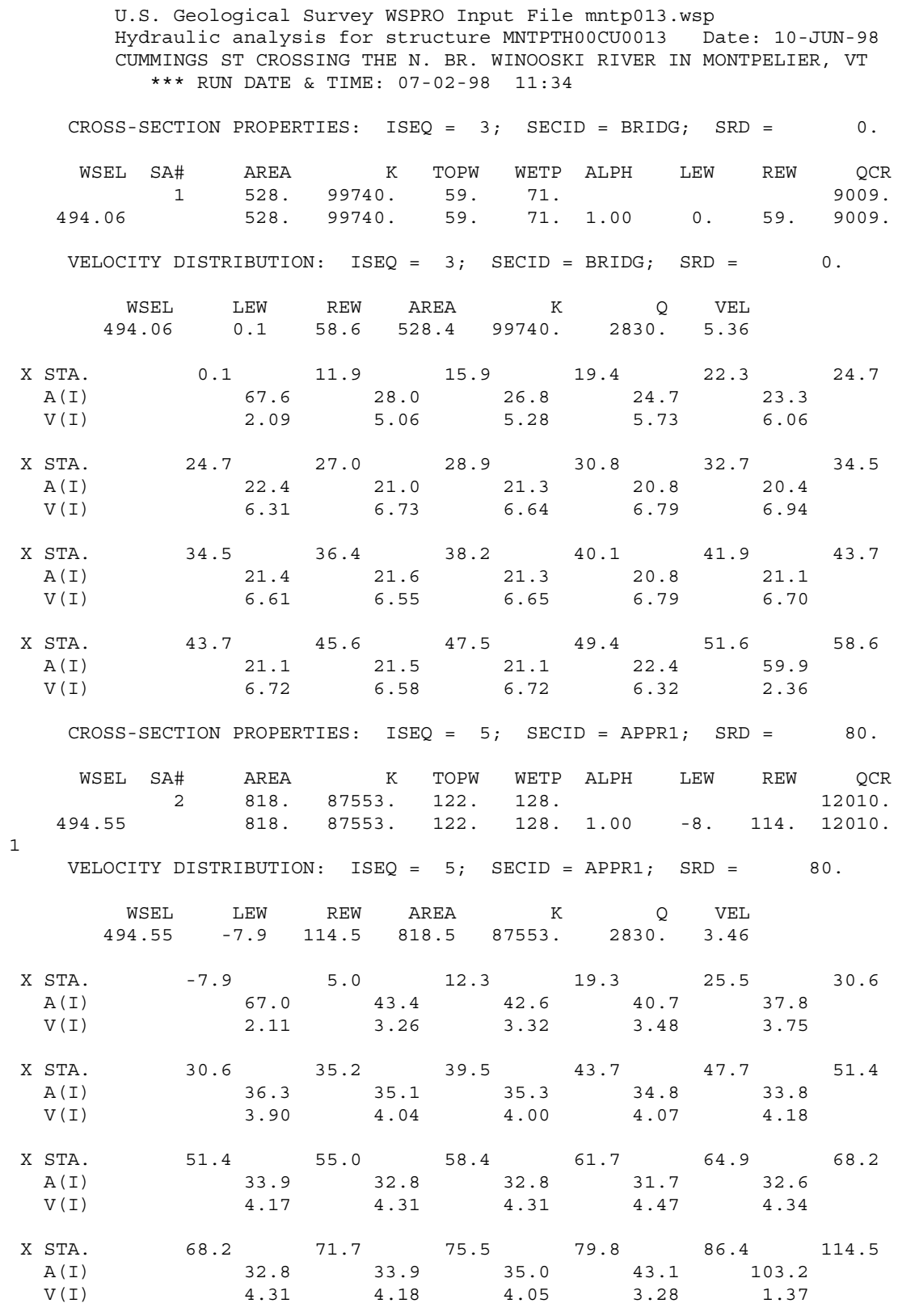


WSPRO OUTPUT FILE (continued)

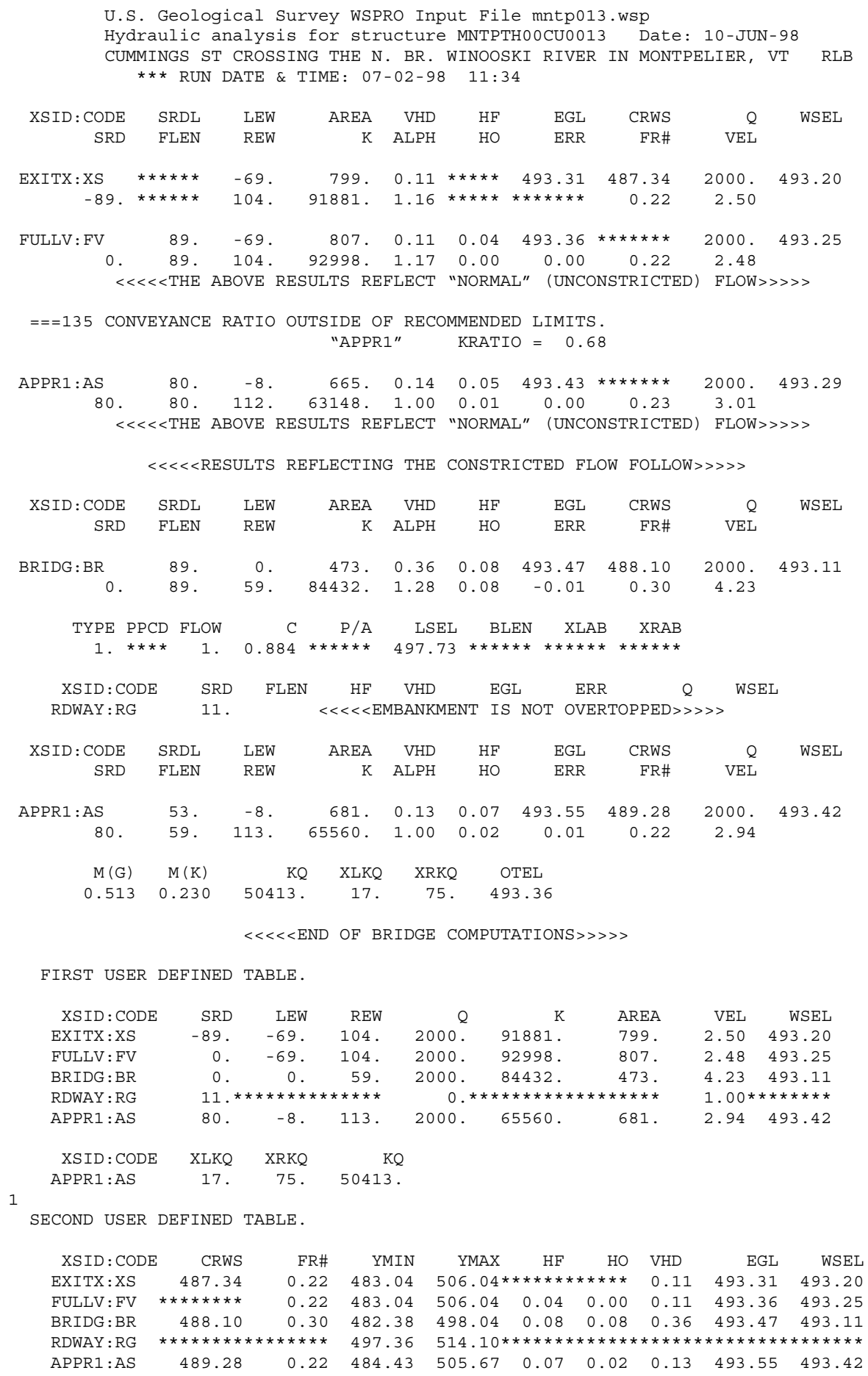


WSPRO OUTPUT FILE (continued)

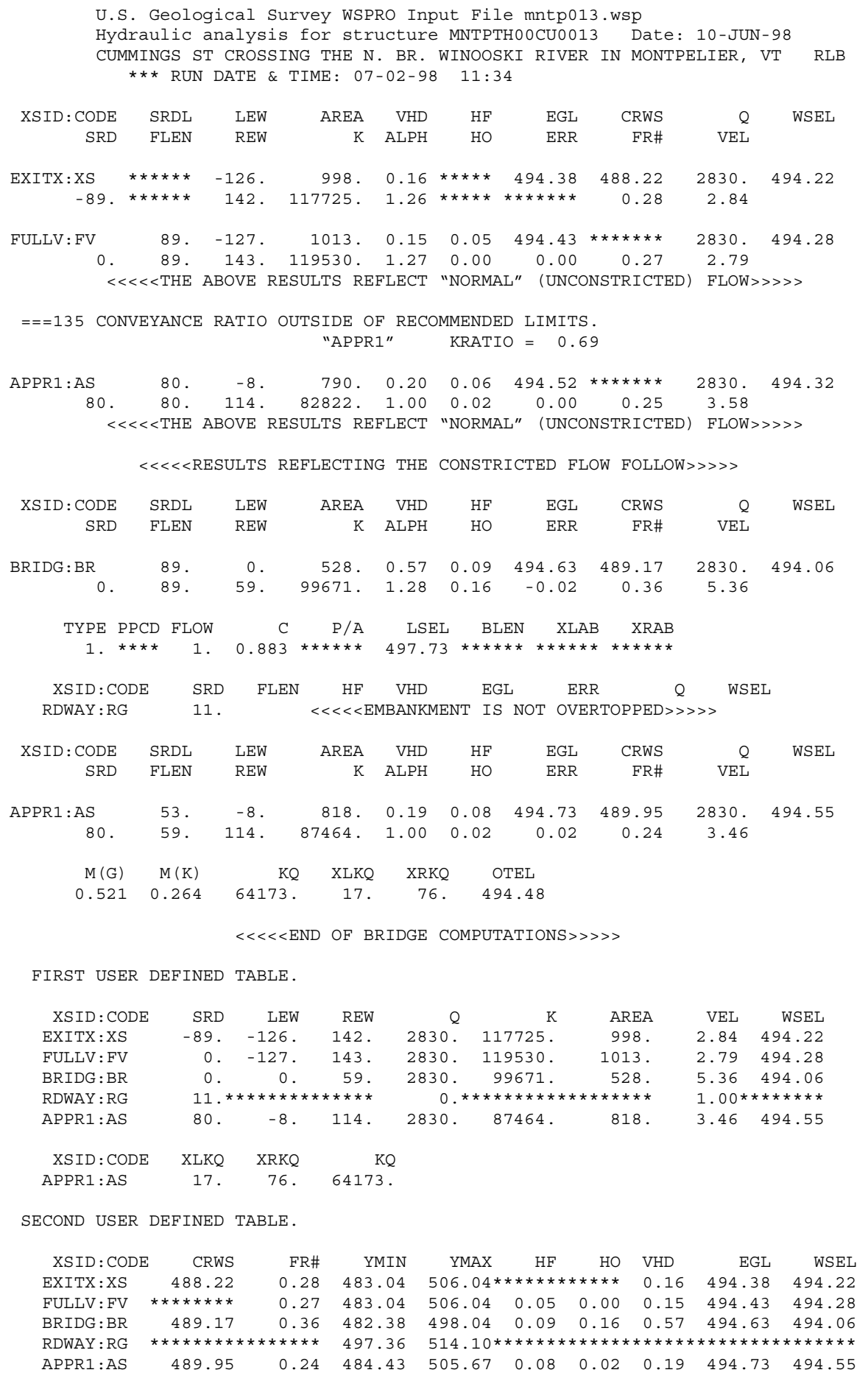




\section{APPENDIX C:}

\section{BED-MATERIAL PARTICLE-SIZE DISTRIBUTION}




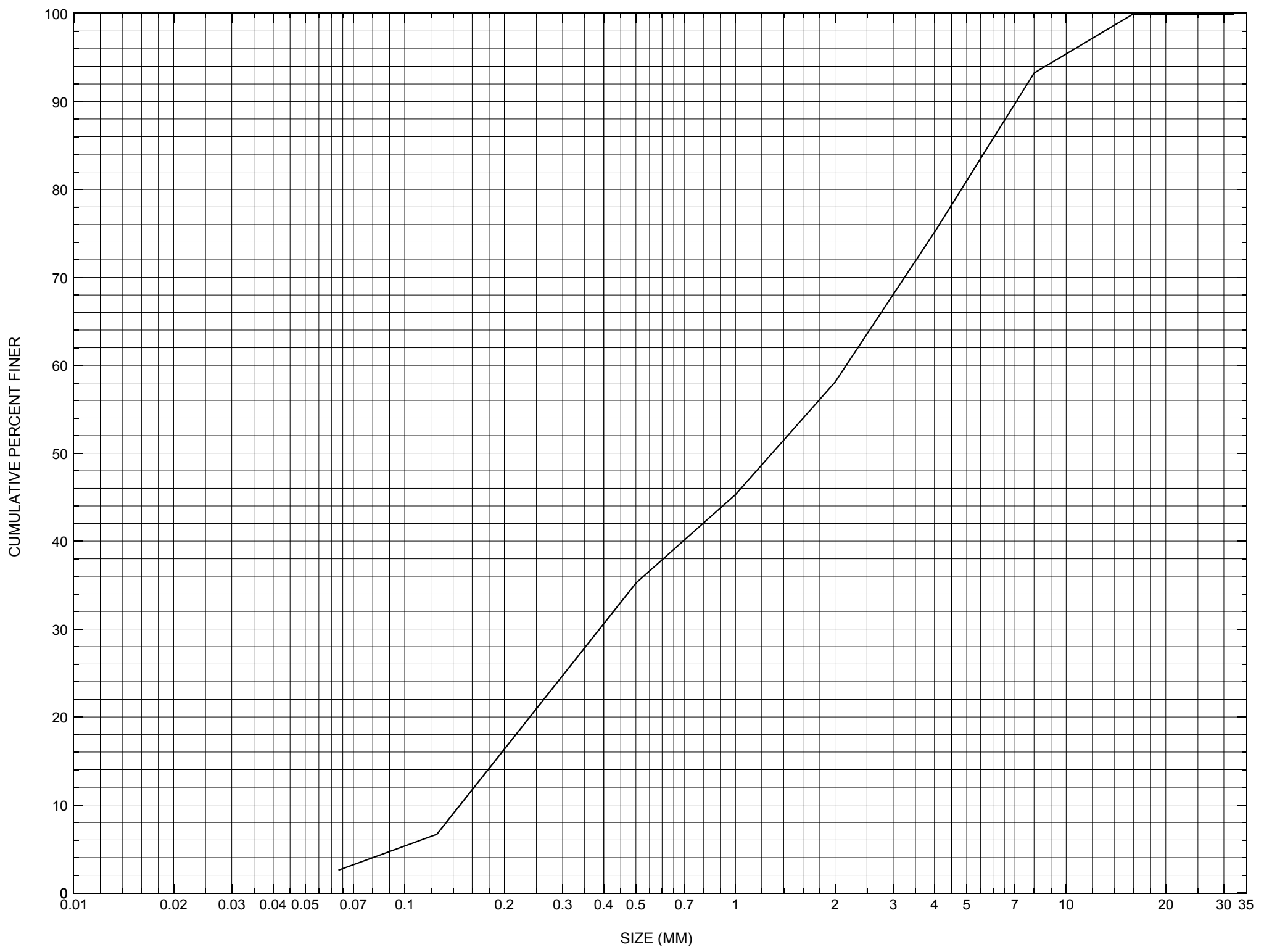

Appendix C. Bed material particle-size distribution for a sieve analysis of a sample from the channel approach of structure MNTPTH00CU0013, in Montpelier, Vermont. 


\section{APPENDIX D: \\ HISTORICAL DATA FORM}




\section{Structure Number MNTPTH00CU0013}

\section{General Location Descriptive}

Data collected by (First Initial, Full last name) $\underline{\mathbf{L}}$. Medalie

Date $(M M / D D / Y Y) \_10 / 13 / \underline{95}$

Highway District Number (I - 2; nn) 06

County (FIPS county code; I - 3; nnn)

Town (FIPS place code; I - 4; nnnnn) $\mathbf{4 6 0 0 0}$

Mile marker (I - 11; nnn.nnn) $\mathbf{0 0 0 0 0 0}$

Waterway (I - 6) NORTH BRANCH WINOOSKI RIVER Road Name (I - 7): -

Route Number C30CU

Topographic Map Montpelier

Latitude (I - 16; nnnn.n) 44163
Vicinity (l - 9) 0.1 MI TO JCT W CL1 TH5

Hydrologic Unit Code: 2010003

Longitude (i - 17; nnnnn.n) $\mathbf{7 2 3 4 2}$

\section{Select Federal Inventory Codes}

FHWA Structure Number $(I$ - 8) $\mathbf{1 0 1 2 1 1 0 0 1 3 1 2 1 1}$

Maintenance responsibility $(I-21 ; n n) \quad \mathbf{0 4}$

Year built (I - 27; YYYY) 1929

Average daily traffic, ADT (I - 29; nnnnnn) 000300

Year of ADT (I - 30; YY) $\mathbf{9 3}$

Opening skew to Roadway $(I-34 ; n n) \quad \mathbf{0 0}$

Operational status $(I-41 ; X) \quad \mathbf{A}$

Structure type (I - 43; nnn) $\mathbf{3 0 2}$

Approach span structure type $(I-44 ; n n n) \quad \mathbf{0 0 0}$

Number of spans (I - 45; nnn) $\underline{\mathbf{0 0 1}}$

Number of approach spans (I - 46; nnnn) $\mathbf{0 0 0 0}$

Comments:

According to the structural inspection report dated 10/19/93, the bridge deck is concrete with an asphalt overlay. The RABUT and its wingwalls have a few fine cracks and small leaks overall, with minor spalling along their bottoms at the water line. The LABUT and its wingwalls have alligator cracks and leaks overall, with some surface spalling along the wingwalls at the water line. Some stone fill is present around the end of the wingwalls on each abutment, with a small pile of laid up granite blocks at the left end of the LABUT. Channel scour is approximately $8 \mathrm{ft}$ deep at the RABUT and $2 \mathrm{ft}$ deep at the LABUT. The US and DS channel embankments show signs of erosion from past flooding. (Continued, page 31) 


\section{Bridge Hydrologic Data}

Is there hydrologic data available? $\underline{\mathbf{N}}$ if No, type ctrl-n $h \quad$ VTAOT Drainage area $\left(m i^{2}\right)$ : -

Terrain character:

Stream character \& type: -

Streambed material:

Discharge Data (cfs):

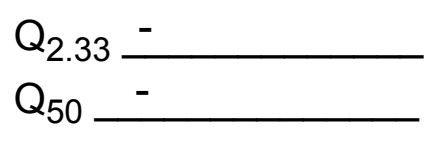

Record flood date $(M M / D D / Y Y):-{ }^{\prime}-$
Estimated Discharge $(c f s):-$

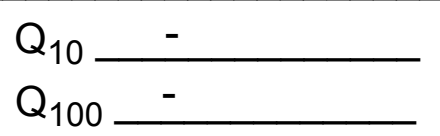

$\mathrm{Q}_{25}$

Water surface elevation $(f t):-$ $(\mathrm{ft} / \mathrm{s}):$

Ice conditions (Heavy, Moderate, Light) : -

Debris (Heavy, Moderate, Light):

The stage increases to maximum highwater elevation (Rapidly, Not rapidly):

The stream response is (Flashy, Not flashy):

Describe any significant site conditions upstream or downstream that may influence the stream's stage: -

Watershed storage area (in percent):

The watershed storage area is: - (1-mainly at the headwaters; 2- uniformly distributed; 3-immediatly upstream oi the site)

Water Surface Elevation Estimates for Existing Structure:

\begin{tabular}{|l|l|l|l|l|l|}
\hline Peak discharge frequency & $Q_{2.33}$ & $Q_{10}$ & $Q_{25}$ & $Q_{50}$ & $Q_{100}$ \\
Water surface elevation (ft)) & - & - & - & - & - \\
Velocity (ft/sec) & - & - & - & - & - \\
\hline
\end{tabular}

Long term stream bed changes: -

Is the roadway overtopped below the $\mathrm{Q}_{100}$ ? (Yes, No, Unknown): $\mathbf{U}$ Frequency: -

Relief Elevation (ft):

Discharge over roadway at $Q_{100}\left(f^{3} / \mathrm{sec}\right)$ :

Are there other structures nearby? (Yes, No, Unknown): Upstream distance (miles): Town: If No or Unknown, type ctrl-n os Highway No. :Structure No. :Year Built:

Clear span (ft): Clear Height (ft): Full Waterway $\left(f^{2}\right)$ : 
Downstream distance (miles): Town: Year Built:

Highway No. : Structure No. : Structure Type:

Clear span (ft): Clear Height $(f t)$ : Full Waterway $\left(f^{2}\right)$ :

Comments:

There are branches along the channel bottom from beaver activity.

\section{USGS Watershed Data}

Watershed Hydrographic Data

Drainage area (DA)

Watershed storage (ST)

Bridge site elevation

Main channel length

520

19.47

$10 \%$ channel length elevation $\mathbf{5 4 0}$

Main channel slope

(S) 46.56 $\mathrm{ft} / \mathrm{mi}$ $\%$ mi

Lake/pond/swamp area

1.12 $\mathrm{mi}^{2}$

Headwater elevation 1800 $\mathrm{ft}$ $\mathrm{ft} \quad 85 \%$ channel length elevation $\mathrm{ft}$

Watershed Precipitation Data

Average site precipitation in Average headwater precipitation in

Maximum 2yr-24hr precipitation event $(124,2)$ in

Average seasonal snowfall (Sn) $\mathrm{ft}$ 


\section{Bridge Plan Data}

Are plans available? $\underline{\mathbf{Y}}$ If no, type ctrl-n pl Date issued for construction (MM/YYYY): _- / 1930

Project Number -

Minimum channel bed elevation: $\mathbf{7 5}$

Low superstructure elevation: USLAB $\underline{91.31}$ DSLAB $\underline{91.31}$ USRAB $\underline{91.77}$ DSRAB $\underline{91.77}$
Benchmark location description:
BM \#1: Hydrant at elevation $100 \mathrm{ft}$ on west side of Elm Street approximately $250 \mathrm{ft}$ west of the right bank

Reference Point (MSL, Arbitrary, Other): Arbitrary Datum (NAD27, NAD83, Other): -

Foundation Type: 1

If 1: Footing Thickness $\mathbf{2} \quad$ Footing bottom elevation: $\mathbf{7 4}$

If 2: Pile Type: ___ (1-Wood; 2-Steel or metal; 3-Concrete) Approximate pile driven length: -

If 3: Footing bottom elevation: -

Is boring information available? $\mathbf{N}$ If no, type ctrl-n bi Number of borings taken: -

Foundation Material Type: $\mathbf{3}$ (1-regolith, 2-bedrock, 3-unknown)

Briefly describe material at foundation bottom elevation or around piles:

There is ledge at the bottom of the right abutment.

There is unknown material at the bottom of the left abutment.

Comments:

Footing bottom elevation at the LABUT $=\mathbf{7 4} \mathrm{ft}$. Footing bottom elevation at the downstream end of the RABUT is $82.91 \mathrm{ft}$, upstream end top of footing $=85 \mathrm{ft}$ (see copy of plans).

The low superstructure elevations are the bridge seat elevations from the bridge plans.

From plans, normal high water elevation $=90.4 \mathrm{ft}$; streambed at the LABUT is $78 \mathrm{ft}$. 


\section{Cross-sectional Data}

Is cross-sectional data available? $\underline{\mathbf{Y}}$

If no, type ctrl-n xs

Source (FEMA, VTAOT, Other)? VTAOT

Comments: This cross section is the upstream face. The low chord elevations are from the survey log done for this report on 7/15/96. The low chord to bed length data are from the sketch attached to a bridge inspection report dated 10/18/93.

\begin{tabular}{|c|c|c|c|c|c|c|c|c|c|c|c|}
\hline Station & $\mathbf{0}$ & 22 & 30 & 41 & 49 & 53 & - & - & - & - & - \\
\hline Feature & LAB & & & & & RAB & - & - & - & - & - \\
\hline $\begin{array}{l}\text { Low chord } \\
\text { elevation }\end{array}$ & 497.4 & 497.6 & 497.7 & 497.8 & 497.9 & 498.0 & - & - & - & - & - \\
\hline $\begin{array}{l}\text { Bed } \\
\text { elevation }\end{array}$ & 489.2 & 487.8 & 485.0 & 481.5 & 483.7 & 485.3 & - & - & - & - & - \\
\hline $\begin{array}{l}\text { Low chord } \\
\text { to bed }\end{array}$ & 8.2 & 9.9 & 12.7 & 16.3 & 14.2 & 12.7 & - & - & - & - & - \\
\hline Station & - & - & - & - & - & - & - & - & - & - & - \\
\hline Feature & - & - & - & - & - & - & - & - & - & - & - \\
\hline $\begin{array}{l}\text { Low chord } \\
\text { elevation }\end{array}$ & - & - & - & - & - & - & - & - & - & - & - \\
\hline $\begin{array}{l}\text { Bed } \\
\text { elevation }\end{array}$ & - & - & - & - & - & - & - & - & - & - & - \\
\hline $\begin{array}{l}\text { Low chord } \\
\text { to bed }\end{array}$ & - & - & - & - & - & - & - & - & - & - & - \\
\hline
\end{tabular}

Source (FEMA, VTAOT, Other)?

Comments:

\begin{tabular}{|l|l|l|l|l|l|l|l|l|l|l|l|l|l|}
\hline Station & - & - & - & - & - & - & - & - & - & - \\
\hline Feature & - & - & - & - & - & - & - & - & - & - \\
\hline $\begin{array}{l}\text { Low chord } \\
\text { elevation }\end{array}$ & - & - & - & - & - & - & - & - & - & - & - \\
\hline $\begin{array}{l}\text { Bed } \\
\text { elevation }\end{array}$ & - & - & - & - & - & - & - & - & - & - \\
\hline $\begin{array}{l}\text { Low chord } \\
\text { to bed }\end{array}$ & - & - & - & - & - & - & - & - & - & - & - \\
\hline $\begin{array}{l}\text { Station } \\
\text { Stature }\end{array}$ & - & - & - & - & - & - & - & - & - & - \\
\hline $\begin{array}{l}\text { Feature } \\
\text { Low chord } \\
\text { elevation }\end{array}$ & - & - & - & - & - & - & - & - & - & - & - & - \\
\hline $\begin{array}{l}\text { Bed } \\
\text { levation }\end{array}$ & - & - & - & - & - & - & - & - & - & - \\
\hline $\begin{array}{l}\text { Low chord } \\
\text { to bed }\end{array}$ & - & - & - & - & - & - & - & - & - & - \\
\hline
\end{tabular}




\section{APPENDIX E: \\ LEVEL I DATA FORM}


U. S. Geological Survey

Bridge Field Data Collection and Processing Form

Qa/Qc Check by: $\underline{\mathbf{R B}}$ Date: $10 / \mathbf{1 7 / 9 6}$

\section{Structure Number}

\section{A. General Location Descriptive}

1. Data collected by (First Initial, Full last name) R. FLYNN

2. Highway District Number 06

Date $(M M / D D / Y Y) \underline{07} / \underline{15} / \underline{1996}$

County 023

Waterway (I - 6) N. BRANCH WINOOSKI RIVER

Route Number $\mathbf{C 3 0 C U}$

Mile marker $\underline{00000}$

Town 46000

Road Name CUMMINGS STREET

Hydrologic Unit Code: 2010003

3. Descriptive comments:

Located 0.1 miles to the junction with CL1 TH5.

\section{B. Bridge Deck Observations}
4. Surface cover.
RBUS 2
LBDS 5
RBDS 5
Overall 5

(2b us, ds,lb,rb: 1- Urban; 2- Suburban; 3- Row crops; 4- Pasture; 5- Shrub- and brushland; 6- Forest; 7- Wetland)
5. Ambient water surface... US 1
UB 1
DS 1
(1- pool; 2- riffle)

6. Bridge structure type 1 (1- single span; 2- multiple span; 3- single arch; 4- multiple arch; 5-cylindrical culvert; 6- box culvert; or 7- other)
7. Bridge length 64
(feet)
Span length 61
(feet)
Bridge width 19.1 (feet)

\section{Road approach to bridge:}
8. LB $\underline{1}$ RB $\underline{1}$
( 0 even, 1- lower, 2- higher)
9. LB
RB 1
(1- Paved, 2- Not paved)

10. Embankment slope (run / rise in feet / foot)

US left

US right

\begin{tabular}{|c|c|c|c|}
\hline \multicolumn{2}{|c|}{ Protection } & \multirow{2}{*}{ 13.Erosion } & 14.Severity \\
\hline 11.Type & 12.Cond. & $\mathbf{1}$ & $\mathbf{1}$ \\
\hline $\mathbf{2}$ & $\mathbf{2}$ & $\mathbf{1}$ & $\mathbf{1}$ \\
\hline $\mathbf{0}$ & - & $\mathbf{1}$ & $\underline{\mathbf{3}}$ \\
\hline $\mathbf{0}$ & - & $\mathbf{1}$ \\
\hline $\mathbf{1}$ & $\mathbf{3}$ & $\mathbf{3}$ & $\underline{\mathbf{3}}$ \\
\hline
\end{tabular}

Bank protection types: 0- none; 1- < 12 inches,

2- $<36$ inches; $3-<48$ inches;

4- < 60 inches; 5- wall / artificial levee

Bank protection conditions: 1- good; 2- slumped;

3- eroded; 4- failed

Erosion: 0 - none; 1- channel erosion; 2 -

road wash; 3- both; 4- other

Erosion Severity: 0 - none; 1- slight; 2- moderate; 3- severe

\section{Channel approach to bridge (BF):}

15. Angle of approach: $\mathbf{1 0}$

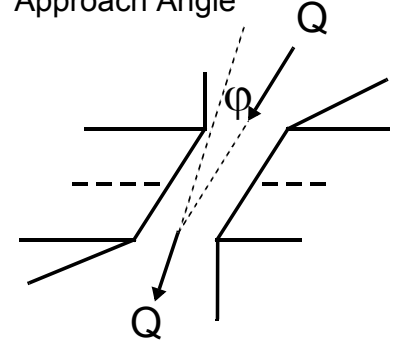

17. Channel impact zone 1:

Where? RB (LB, RB)

Range? 10 feet US

Channel impact zone 2:

Where? RB (LB, RB)

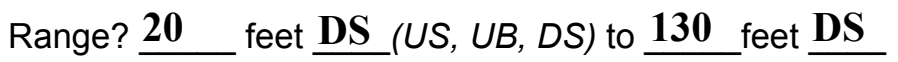

Impact Severity: 0- none to very slight; 1- Slight; 2- Moderate; 3- Severe
16. Bridge skew: $\mathbf{0}$ Bridge Skew Angle

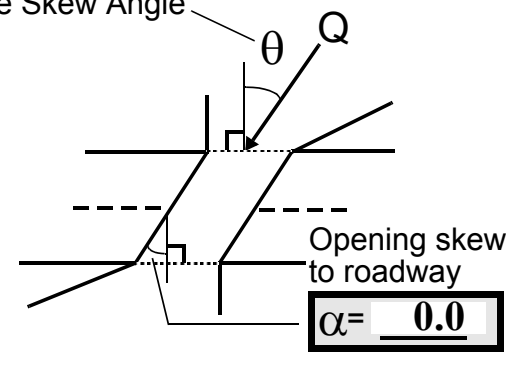

\section{Exist? $\mathbf{Y}(Y$ or $N)$}

Severity 1

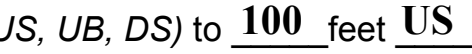

Exist? $\mathbf{Y}(\mathrm{Y}$ or $N)$

Severity 1 
18. Bridge Type: 1a

1a- Vertical abutments with wingwalls

$1 \mathrm{~b}$ - Vertical abutments without wingwalls

2- Vertical abutments and wingwalls, sloping embankment Wingwalls parallel to abut. face

3- Spill through abutments

4- Sloping embankment, vertical wingwalls and abutments

Wingwall angle less than $90^{\circ}$.

19. Bridge Deck Comments (surface cover variations, measured bridge and span lengths, bridge type variations, approach overflow width, etc.)

7. Values are from the VTAOT files. Measured bridge length is $64 \mathrm{ft}$, bridge span is $59.5 \mathrm{ft}$, and the bridge width is $19.1 \mathrm{ft}$.

13. The severe designation of the DS left bank road approach erosion has occurred above the protection and is caused mostly by road wash and eddy currents.

18. The wingwalls are present on the US right and on the DS left corners of the structure. The wingwalls are at 90 degrees (parallel to the roadway) to the abutments on the US left and the DS right corners of the structure.

\section{Upstream Channel Assessment}

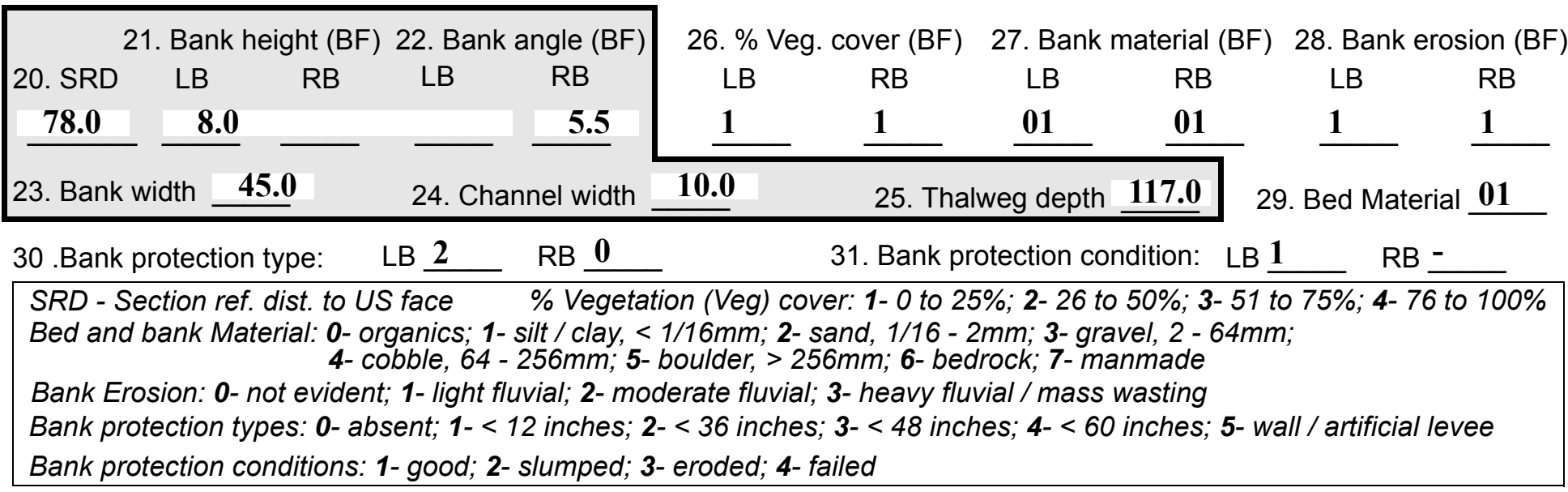

32. Comments (bank material variation, minor inflows, protection extent, etc.):

28. The banks are scalloped and some tree roots are exposed along the banks.

30. The left bank protection US is type-2 from $0 \mathrm{ft}$ US to $30 \mathrm{ft}$ US and type-1 from $30 \mathrm{ft}$ US to $70 \mathrm{ft}$ US. 
36. Point bar extent: 20 feet $\underline{\mathbf{U S}}$ (US, UB) to $1 \mathbf{1 0 0}$ feet $\underline{\mathbf{U S}}$ (US, UB, DS) positioned $\underline{\mathbf{0}} \%$ LB to 30 \%RB

37. Material: $\mathbf{3 2 1}$

38. Point or side bar comments (Circle Point or Side; Note additional bars, material variation, status, etc.):

39. Is a cut-bank present? $\mathbf{Y}$ ( $Y$ or if $N$ type ctrl-n $c b)$

40. Where? $\underline{\mathbf{R B}}$ (LB or RB)

41. Mid-bank distance: $\mathbf{8 0}$

42. Cut bank extent: $\mathbf{3 0}$

43. Bank damage: 1

(1- eroded and/or creep; 2- slip failure; 3- block failure)

44. Cut bank comments (eg. additional cut banks, protection condition, etc.):

There is no protection on this part of the bank, which is mostly organics. Tree roots are exposed.

45. Is channel scour present? $\mathbf{Y}$ ( $Y$ or if $N$ type ctrl-n cs) 46. Mid-scour distance: 0 DS

47. Scour dimensions: Length $\underline{\mathbf{1 4 0}}$ Width $\underline{\mathbf{4 0}}$ Depth : $\underline{\mathbf{8}}$ Position $\underline{\mathbf{5 0}} \%$ LB to $\underline{\mathbf{8 0}} \%$ RB

48. Scour comments (eg. additional scour areas, local scouring process, etc.):

The US scour extends under the bridge and DS along the right side of the channel. Scour is from $50 \mathrm{ft}$ US to

$70 \mathrm{ft}$ DS with mid-scour at the DS bridge face.

49. Are there major confluences? $\mathbf{N}$

51. Confluence 1: Distance Confluence 2: Distance -

54. Confluence comments (eg. confluence name):

NO MAJOR CONFLUENCES
( $Y$ or if $N$ type ctrl-n $m c$ )

52. Enters on -

Enters on ( $L B$ or $R B)$ ( $L B$ or $R B)$
50. How many? -

53. Type(1-perennial; 2- ephemeral)

Type (1- perennial; 2- ephemeral)

NO MAJOR CONFLUENCES

\section{Under Bridge Channel Assessment}

55. Channel restraint (BF)? LB 2

\begin{tabular}{|ccccc}
\hline \multicolumn{2}{|c}{ 56. Height (BF) } & \multicolumn{3}{c}{57 Angle (BF) } \\
LB & RB & LB & RB \\
$\mathbf{9 6 . 5}$ & & & $\mathbf{6 . 0}$ & \\
\hline
\end{tabular}

58. Bank width (BF) -

59. Channel width -
62. Erosion (BF)

LB RB

7
63. Bed Material -

Bed and bank Material: 0- organics; 1- silt / clay, < 1/16mm; 2- sand, 1/16 - 2mm; 3- gravel, 2 - 64mm; 4- cobble, 64 - 256mm; 5- boulder, > 256mm; 6- bedrock; 7- manmade

Bank Erosion: 0- not evident; 1- light fluvial; 2- moderate fluvial; 3- heavy fluvial / mass wasting

64. Comments (bank material variation, minor inflows, protection extent, etc.):

01 
65. Debris and Ice Is there debris accumulation?

(Yor $N)$ 66. Where? $\mathbf{N}$

(1- Upstream; 2- At bridge; 3- Both)

67. Debris Potential ( 1- Low; 2- Moderate; 3- High)

68. Capture Efficiency 1 (1-Low; 2- Moderate; 3- High)

69. Is there evidence of ice build-up? 1 (Y or $N)$

Ice Blockage Potential $\mathbf{N}$ (1-Low; 2- Moderate; 3- High)

70. Debris and Ice Comments:

2

Local residents commented that ice jams are common in the winter.

\begin{tabular}{|l|c|c|c|c|c|c|c|c|}
\hline Abutments & $\begin{array}{c}\text { 71. Attack } \\
\angle \text { (BF) }\end{array}$ & $\begin{array}{c}\text { 72. Slope } \angle \\
\text { (Qmax) }\end{array}$ & $\begin{array}{c}\text { 73. Toe } \\
\text { loc. (BF) }\end{array}$ & $\begin{array}{c}\text { 74. Scour } \\
\text { Condition }\end{array}$ & $\begin{array}{c}75 . \text { Scour } \\
\text { depth }\end{array}$ & $\begin{array}{c}\text { 76. Exposure } \\
\text { depth }\end{array}$ & 77. Material & 78. Length \\
\hline LABUT & & $\mathbf{0}$ & $\mathbf{9 0}$ & $\mathbf{2}$ & $\mathbf{0}$ & - & - & $\mathbf{9 0 . 0}$ \\
\hline RABUT & $\mathbf{1}$ & $\mathbf{0}$ & $\mathbf{9 0}$ & & & $\mathbf{2}$ & $\mathbf{1}$ & $\mathbf{5 9 . 0}$ \\
\hline
\end{tabular}

Pushed: $L B$ or RB

Toe Location (Loc.): 0- even, 1- set back, 2- protrudes

Scour cond.: 0- not evident; 1- evident (comment); 2- footing exposed; 3-undermined footing; 4- piling exposed; 5- settled; 6- failed

Materials: 1- Concrete; 2- Stone masonry or drywall; 3- steel or metal; 4- wood

79. Abutment comments (eg. undermined penetration, unusual scour processes, debris, etc.):

8

1

73. There is deep sediment along the left abutment. Either the footing or rock protection is located under $1 \mathrm{ft}$ of sediment, 2 ft below the present water surface.

74. There is protection at the base of the right abutment which extends $3 \mathrm{ft}$ into the channel and slopes into the scour hole.

80. Wingwalls:

Exist? Material? Scour Scour Exposure $\begin{aligned} & 81 . \\ & \text { Angle? Length? }\end{aligned}$ Condition? depth? depth?

USLWW:

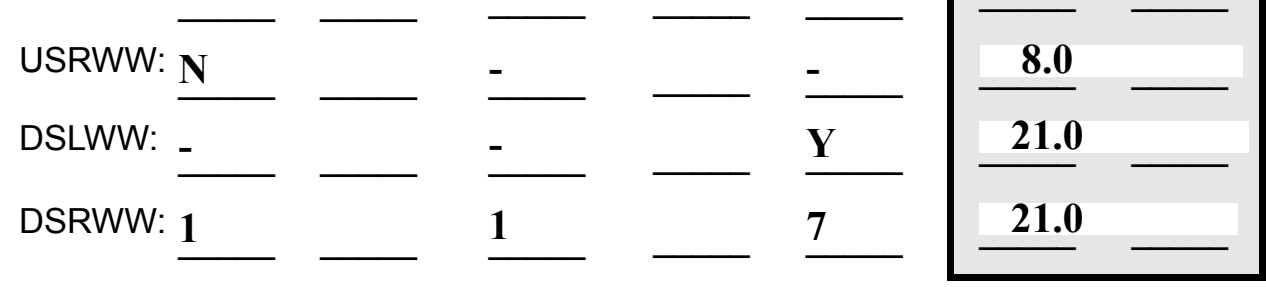

Wingwall materials: 1- Concrete; 2- Stone masonry or drywall; 3- steel or metal; 4- wood

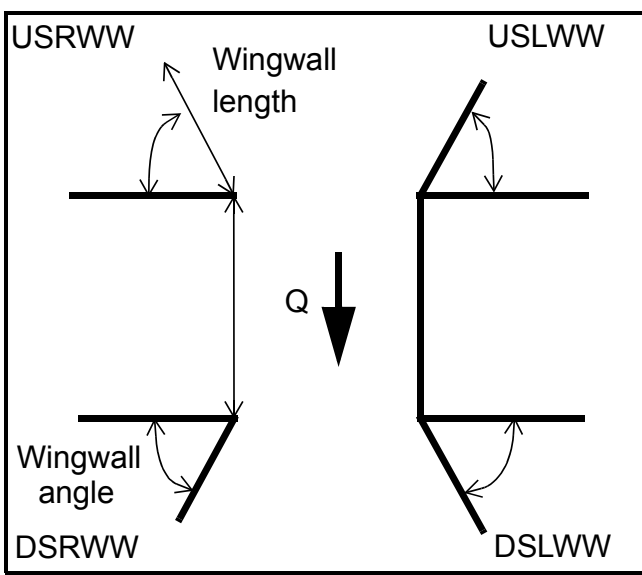

82. Bank / Bridge Protection:

\begin{tabular}{|l|l|l|l|l|l|l|l|c|}
\hline Location & USLWW & USRWW & LABUT & RABUT & LB & RB & DSLWW & DSRWW \\
\hline Type & $\mathbf{0}$ & $\mathbf{0}$ & $\mathbf{N}$ & - & - & - & - & $\mathbf{1}$ \\
\hline Condition & $\mathbf{Y}$ & - & - & - & - & - & - & $\mathbf{1}$ \\
\hline Extent & $\mathbf{1}$ & - & - & - & $\mathbf{0}$ & $\mathbf{0}$ & $\mathbf{2}$ & - \\
\hline
\end{tabular}

Bank / Bridge protection types: 0- absent; 1- < 12 inches; 2- < 36 inches; 3- < 48 inches; 4- < 60 inches; 
83. Wingwall and protection comments (eg. undermined penetration, unusual scour processes, etc.):

-
-
-
-
2
1
1
-
-
-

\section{Piers:}

84. Are there piers? _ _ (Y or if $N$ type ctrl-n pr)

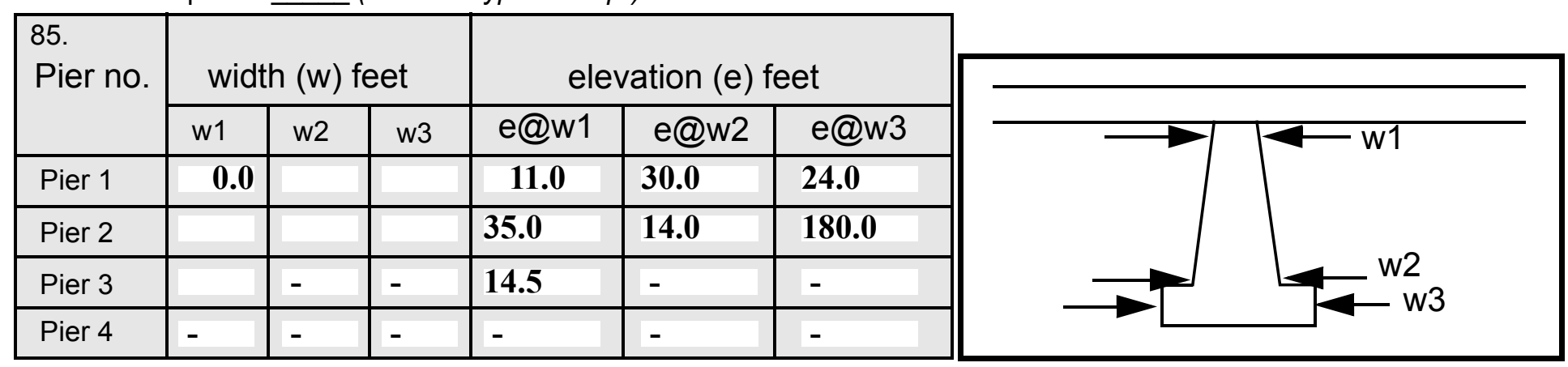

\begin{tabular}{|c|c|c|c|c|}
\hline Level 1 Pier Descr. & 1 & 2 & 3 & 4 \\
\hline 86. Location (BF) & & - & - & - \\
\hline 87. Type & & - & - & - \\
\hline 88. Material & & - & - & - \\
\hline 89. Shape & & - & - & - \\
\hline 90. Inclined? & & - & - & - \\
\hline 91. Attack $\angle(\mathrm{BF})$ & & - & - & - \\
\hline 92. Pushed & & - & - & - \\
\hline 93. Length (feet) & - & - & - & - \\
\hline 94. \# of piles & & - & - & - \\
\hline 95. Cross-members & & - & - & - \\
\hline 96. Scour Condition & & - & - & - \\
\hline 97. Scour depth & $\mathbf{N}$ & - & - & - \\
\hline 98. Exposure depth & - & - & - & - \\
\hline
\end{tabular}

LFP, LTB, LB, MCL, MCM, MCR, RB, RTB, RFP

1- Solid pier, 2- column, 3- bent

1-Wood; 2- concrete; 3- metal; 4- stone

1- Round; 2- Square; 3- Pointed

Y-yes; $N-$ no

$L B$ or $R B$

0- none; 1- laterals; 2- diagonals; 3- both

0- not evident; 1- evident (comment);

2- footing exposed; 3- piling exposed;

4- undermined footing; 5- settled; 6- failed 
99. Pier comments (eg. undermined penetration, protection and protection extent, unusual scour processes, etc.):

-
-
-
-
-
-
-
-
-
-

100.

\section{E. Downstream Channel Assessment}

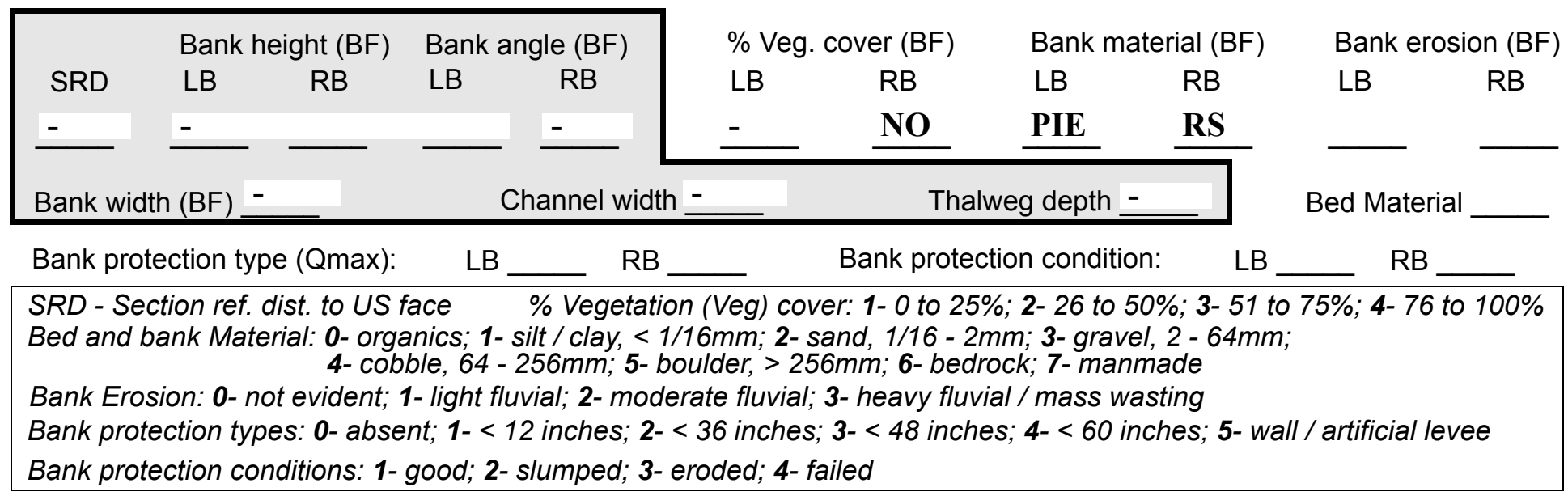

Comments (eg. bank material variation, minor inflows, protection extent, etc.):

2
1
01
01
2
2
01
0
0
-
-

Protection on left bank is described as the DS left wingwall protection in question 82 .

101. Is a drop structure present? ___ ( $Y$ or $N$, if $N$ type ctrl-n ds) 102. Distance: ___ feet

103. Drop: ___ feet 104. Structure material:___ (1- steel sheet pile; 2- wood pile; 3- concrete; 4- other)

105. Drop structure comments (eg. downstream scour depth): 
Point bar extent: feet

(US, UB, DS) to $\underline{\mathbf{N}}$ feet (US, UB, DS)

DS) positioned \%LB to DR \%RB

Material: $\mathbf{O P}$

Point or side bar comments (Circle Point or Side; note additional bars, material variation, status, etc.):

\section{STRUCTURE}

Is a cut-bank present? (Y or if $N$ type ctrl- $n$ cb) Where? (LB or $R B)$

Mid-bank distance: $\underline{\mathbf{Y}}$ Cut bank extent: 100 feet $\underline{\mathbf{2 5}}$ (US, UB, DS) to $\underline{\mathbf{7 0}}$ feet $\underline{\mathrm{DS}}$ (US, UB, DS)

Bank damage: 120 (1-eroded and/or creep; 2- slip failure; 3- block failure)

Cut bank comments (eg. additional cut banks, protection condition, etc.):

DS

o

50

3210

Is channel scour present? _-_ (Y or if N type ctrl-n cs) Mid-scour distance:

Scour dimensions: Length Width Depth: $\mathbf{Y}$

Positioned $\underline{\text { RB }} \%$ LB to $\underline{\mathbf{4 0}} \% \mathrm{RB}$

Scour comments (eg. additional scour areas, local scouring process, etc.):

10

DS

65

DS

Are there major confluences? 1 ( $Y$ or if $N$ type ctrl-n $m c)$

How many? -

Confluence 1: Distance

Enters on ( $L B$ or $R B)$

Type ( 1- perennial; 2- ephemeral)

Confluence 2: Distance $\mathbf{N}$

Enters on (LB or $R B)$

Type (1- perennial; 2- ephemeral)

Confluence comments (eg. confluence name):

\section{F. Geomorphic Channel Assessment}

107. Stage of reach evolution -

1- Constructed

2- Stable

3- Aggraded

4- Degraded

5- Laterally unstable

6- Vertically and laterally unstable 
108. Evolution comments (Channel evolution not considering bridge effects; See HEC-20, Figure 1 for geomorphic descriptors):

$-$

NO CHANNEL SCOUR

Channel scour continues from US. See US channel assessment.

$\mathbf{N}$

$-$

$-$

$-$

$-$

-

- 


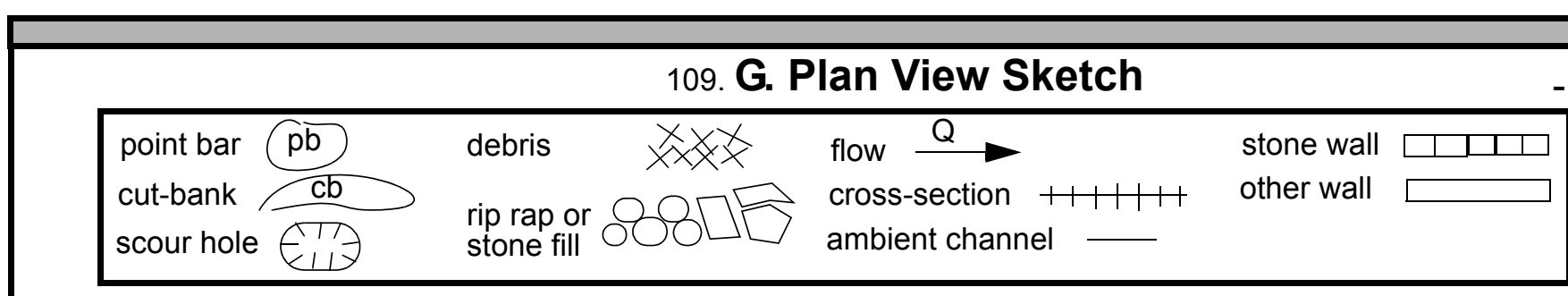


APPENDIX F:

SCOUR COMPUTATIONS 


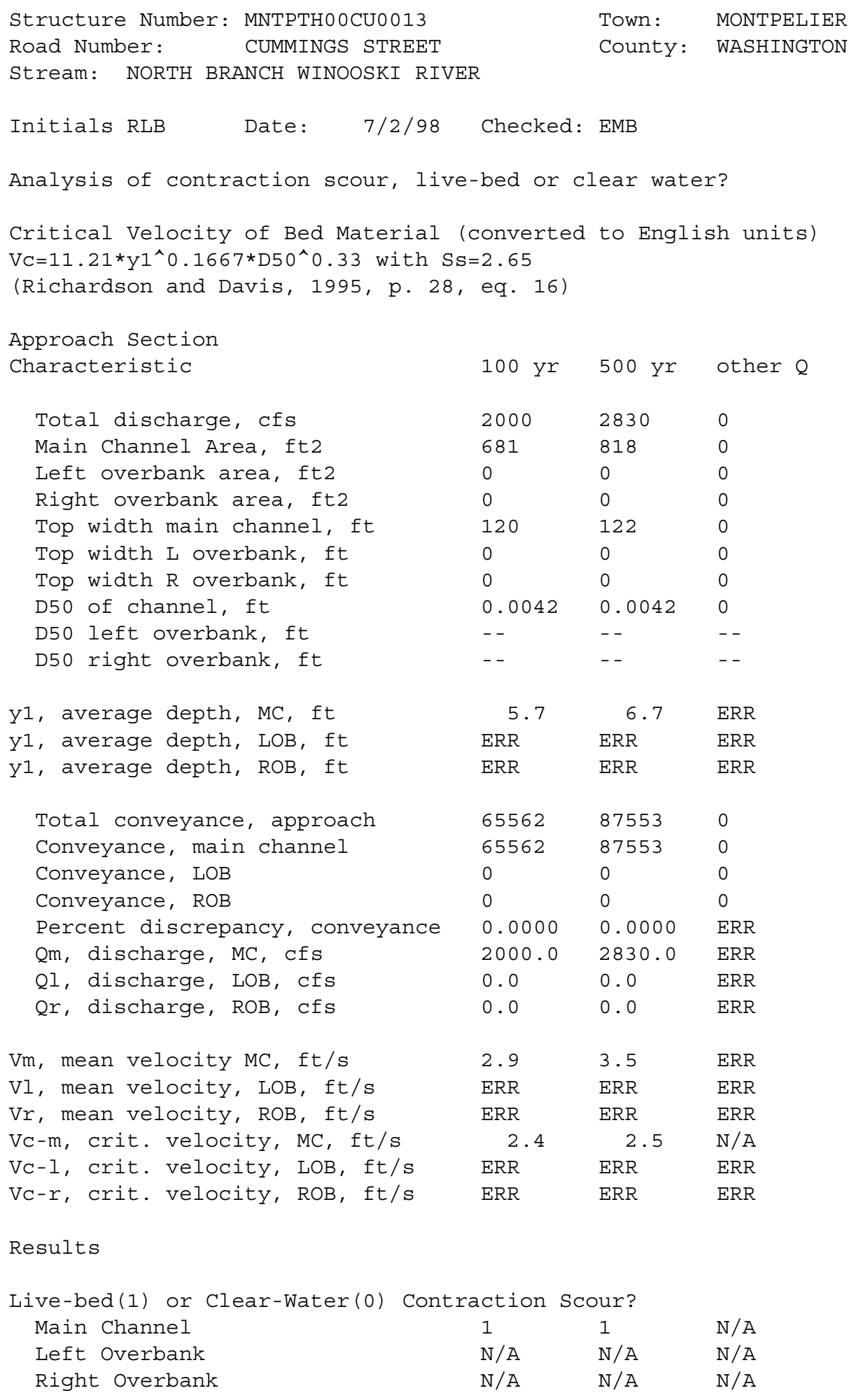




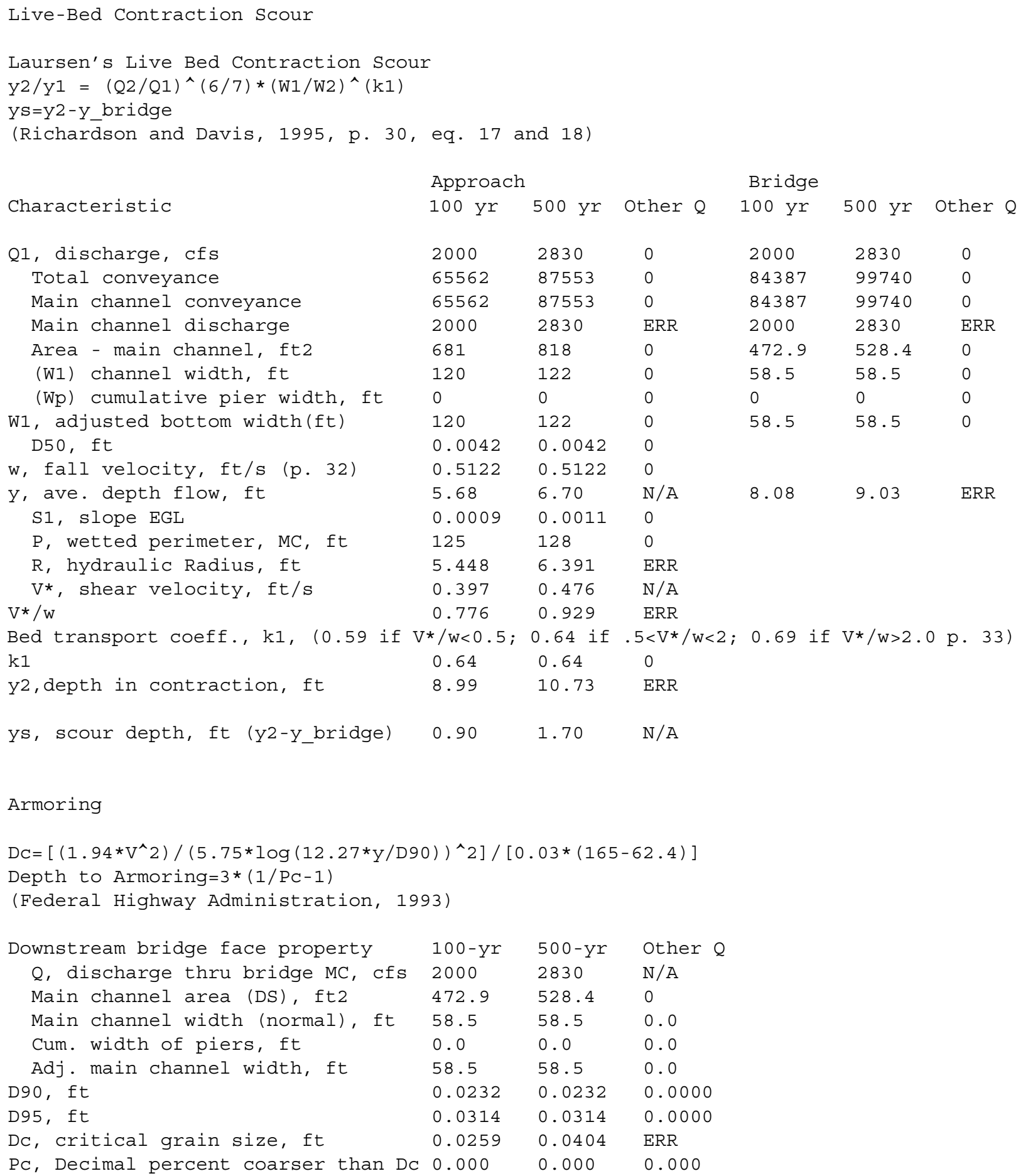




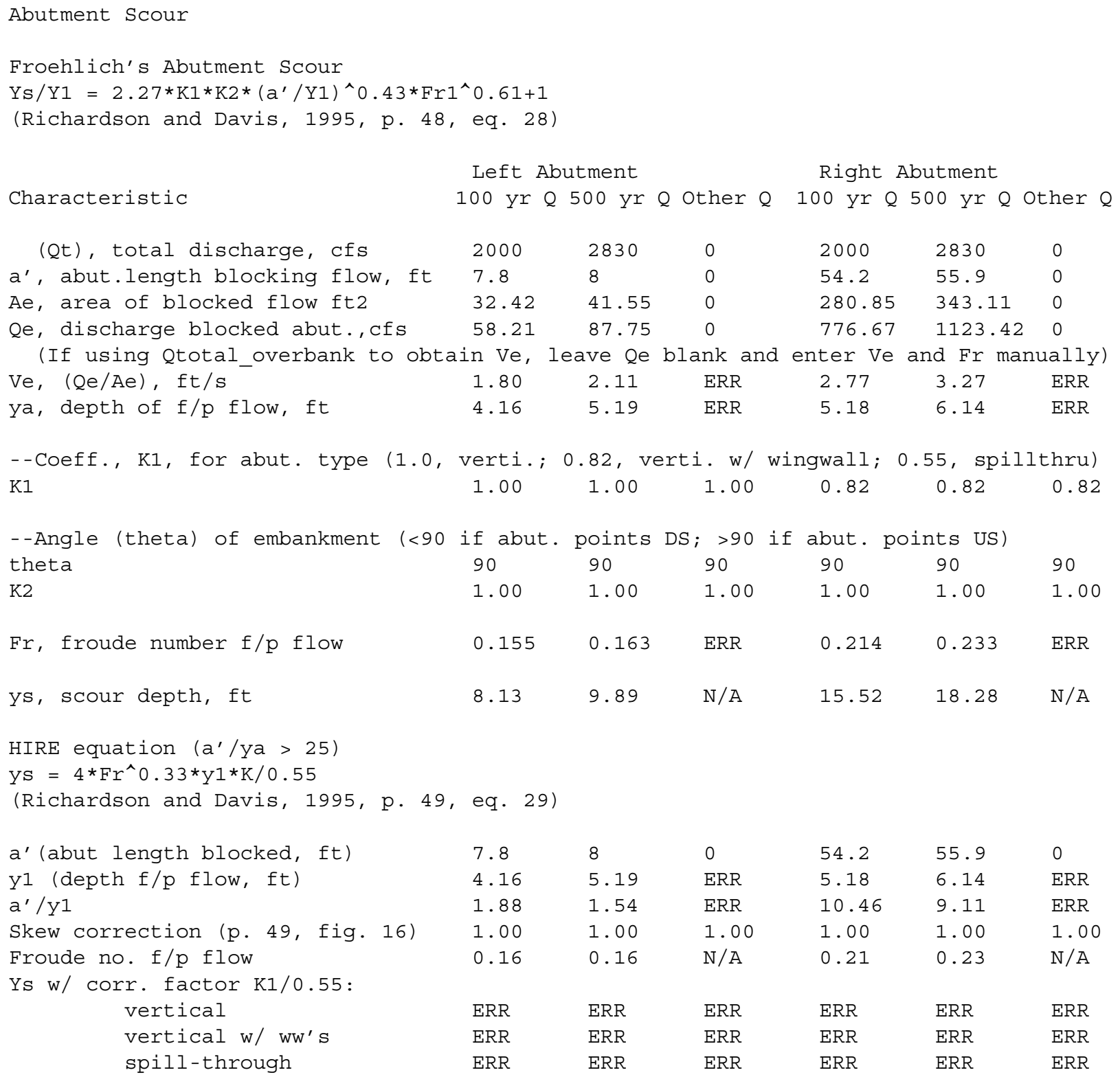




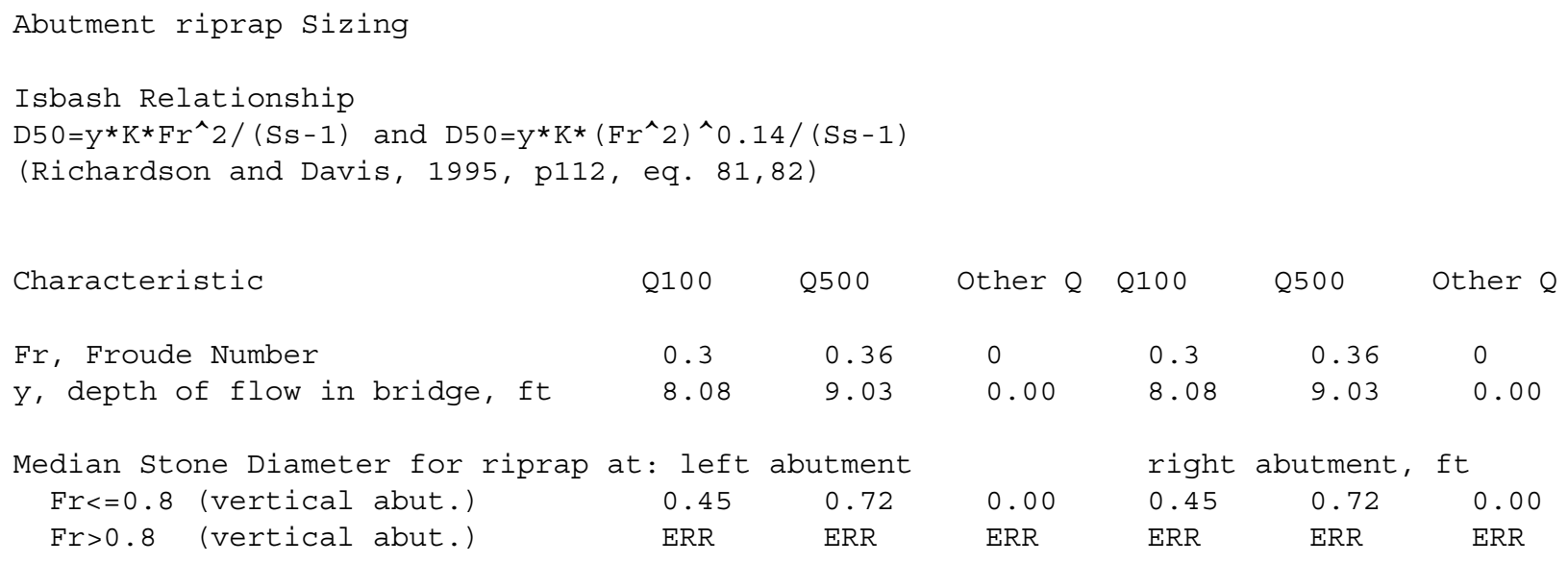

